
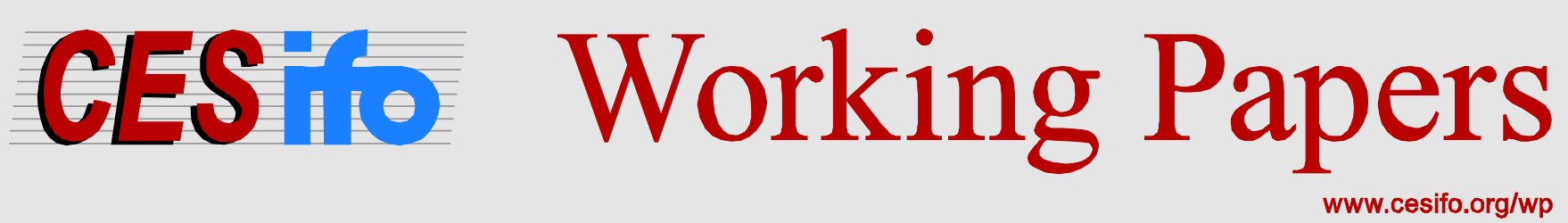

\title{
The Evaluation of Pension Reforms in the Public Sector: A Case Study of the Paris Subway Drivers
}

\author{
Touria Jaaidane \\ Robert J. Gary-Bobo
}

CESIFO WORKING PAPER NO. 5431

CATEgORY 1: PUBLIC FINANCE

JULY 2015

An electronic version of the paper may be downloaded

- from the SSRN website:

- from the RePEc website:

- from the CESifo website:

WwW.SSRN.com

Www.RePEc.org

www.CESifo-group.org/wp 


\title{
The Evaluation of Pension Reforms in the Public Sector: A Case Study of the Paris Subway Drivers
}

\begin{abstract}
To evaluate pension reforms in public services, we put forward a simple criterion, the actuarial cost of a worker, per year of service. This measure of cost is the expected, discounted sum of net real wages and pension benefits, earned by a worker over his entire life cycle, divided by the number of years of service. We show the possibility of reforms such that (i), the actuarial cost of a worker per year of service is reduced, (ii) the utility of workers does not decrease and (iii) the pension fund deficits do not increase. Workers can willingly postpone retirement in exchange for increased final salaries and pensions. Present and future public subsidies may at the same time be reduced. We propose a quantitative analysis of the 2008 reform of the Paris Metro pensions. Focusing on the case of train drivers, we show that the reform should save public funds, but only in the long run. During a long transition period, the reform is likely to end up with larger State subsidies to the pension scheme. The reform can be interpreted as a deal between public authorities and insiders at the expense of recent recruits. A reform preserving the public budget from an outright increase in social costs could have been both technically feasible and politically acceptable.
\end{abstract}

JEL-Code: H550, J260, J450.

Keywords: pensions, reform public sector, transportation workers.

Touria Jaaidane

LEM (Lille Économie Management)

University of Lille

Lille / France

touria.jaaidane@univ-lille1.fr
Robert J. Gary-Bobo

CREST-ENSAE

15 boulevard Gabriel Peri

France - 92245 Malakoff cedex

robert.gary-bobo@ensae.fr 


\section{Introduction}

The reform of public-sector pension schemes poses difficult problems in many countries. It may seem surprising that these problems are very similar in countries with rather different social insurance systems, like continental Europe and the United States. The demographic trends - retirees living longer —, the declining ratios of active employees to beneficiaries, are not the only difficulties. Over the years, local government and public firm employees have negotiated relatively generous special pension provisions, that finally happen to be unsustainable. In the midst of the current public debt crisis, an increasing amount of public funds, in the form of government subsidies, must be channeled to these pension regimes, forcing local politicians to consider tax increases.

To further illustrate the importance of the topic, some common features of the French and US public pension systems can be underlined. Both French public-sector employees and the vast majority of US state and local public employees are entitled to a definedbenefit pension scheme, under which the payment of benefits is, in essence, guaranteed by the taxpayers. ${ }^{1}$ In both countries, retirement benefits are computed as a fraction of the employee's final salary, depending on the number of years of service.

Both the French and US Social Security programs are pay-as-you-go systems, while the US state pension plans are typically funded by a mix of assets. These public pension plans require predetermined contributions of participants (usually a percentage of salary). The two countries face funding deficits and the taxpayer subsidy problem is similar. Unfunded pension liabilities are a federal, a state-level and a municipal issue. It seems that there is a common Political Economy problem.

As of August 2010, the present value of unfunded Social Security liabilities was approximately $\$ 5.4$ trillion. This is the amount that should be set aside today in order for the shortfall to be covered, by principal and interest, over the next 75 years. Many US states have underfunded pension schemes. As of 2010, the state pension shortfall ranges between $\$ 700$ billion and $\$ 3$ trillion, depending on the discount rate used to value future liabilites. ${ }^{2}$ US cities and municipalities also have pension programs. The unfunded liabilities for these programs are as high as $\$ 574$ billion. On average, pensions consume nearly 20 percent of municipal budgets. In 2013, several American cities filed for bankruptcy protection under federal laws.

In France, the pension liability for the state civil service alone (i.e., central government employees) totals slightly more than 1000 billions euros at the end of 2014, when discounted at the real interest rate $^{3}$ of $2 \%$. This represents almost $50 \%$ of the French GDP in 2014.

In what follows, we present a quantitative evaluation of the Paris subway pension reform, enacted in 2008. We focus on the particular and well-known case of the highly

\footnotetext{
${ }^{1}$ According to the 2014 National Compensation Survey on retirement benefits published by the Bureau of Labor Statistics, $83 \%$ of local and state employees have access to defined-benefits plans in the United States.

${ }^{2}$ The $\$ 700$ billion figure is based on using a discount rate in the $8 \%$ range, representative of historical pension-fund investment returns, while the $\$ 3$ trillion represents a discount rate in the $5 \%$ range, representative of historical Treasury bond ("risk-free") yields. Novy-Marx and Rauh (2011a, 2011b), advocate the use of the interest rate on bonds to avoid the underestimation of liabilities.

${ }^{3}$ The discount rate used by the French National Assembly is the interest rate on inflation-indexed government bonds with a 2029 maturity. However, it seems problematic to use an interest rate of $0.38 \%$, which is a historical low, to discount pension liabilities. A rate of $2 \%$ is more conservative.
} 
strike-prone train drivers. The employer of Paris subway drivers, called RATP ${ }^{4}$, is a public transportation company. It is the Parisian equivalent of the Metropolitan Transportation Authority in New-York, of Chicago's CTA and of London Underground Ltd. The RATP special pension scheme is directly subsidized by the French State: 50\% of the pension fund resources are paid out of the national budget.

Pension reform has always been a source of severe social unrest in France, and the resistance of public transportation workers is particularly strong. Until recently, the Paris train drivers were allowed to retire at the age of 50, after 25 years of career, and with a relatively generous pension. The political acceptability of further changes in rules applying to all pensions - notably an increase in the retirement age, which is among the lowest in Europe - clearly hinges on the abolition of some public sector privileges. But, again, this is not typically French: the generosity towards public employees may also characterize the situation in many countries, including the United States, although this point is hotly debated. ${ }^{5}$

During the fall of 2007, the newly elected president, Nicolas Sarkozy, pressed for a reform of the Paris Metro, and of other special pension schemes. Given the importance of the interests at stake, it is at first glance surprising that an agreement was reached, after a few days of strike only, between the transportation company, the unions and the government, in December 2007. At the time, a number of observers were puzzled by the speed at which such a difficult pension-reform problem had been solved by the company and public authorities.

To evaluate the reform of pensions in a company owned by the State, its pension liabilities may be viewed as costs for a consolidated public entity merging the company and its pension fund. Pension systems should not be evaluated independently of the firm's career systems. We rely on a simple criterion, the actuarial cost of a worker per year of service. This concept is different from the ARC, the annual required contribution. Our proposed measure takes the full value of careers into account. ${ }^{6}$ By definition, actuarial cost per year of service is the expected, discounted sum of real net wages and pension benefits earned by an agent over his(her) entire life cycle, divided by the length of service, in years. Expectations are taken using survival probabilities (i.e., life tables). Indexation of benefits and wages to inflation, as measured by the consumer price index, is assumed perfect. The public manager should seek to minimize this actuarial cost per employee and per year of service, under the constraint that production meets the public target, and participation constraints. For instance, the actuarial cost of subway drivers should be minimized subject to the constraint that metro trains continue to run and to transport the required number of people each day from home to work. Public authorities save money permanently if they manage to reduce the actuarial

\footnotetext{
${ }^{4}$ The Régie Autonome des Transports Parisiens.

${ }^{5}$ See Biggs (2014).

${ }^{6}$ In the U.S., the public pension plans are required to meet annual required contribution (i.e., ARC) goals each year. The employer contributions under these plans should fill the gap between actuarially required contributions and employee contributions. An ARC includes payment of the present value of any newly accrued benefits and a portion of a plan's unfunded liability. As shown by Novy-Marx and Rauh, roughly $45 \%$ of state government systems paid less than the full ARC they owed during 2009. A full quarter of those in the Novy-Marx and Rauh (2011) sample paid less than 80\%, and the mean retirement plan (of those that did not pay the full ARC) covered only $73 \%$ of its ARC during 2009. The ARC is a typical actuarial value that approximates a per-year value. That is clearly different from the one we are advocating here - that accounts for the pension liabilities but also the career value of employees.
} 
cost per year of service. As a consequence, the present value of pension liabilities, added to the value of the commitment to offer lifetime careers within the firm is reduced, and public subsidies to the company and its pension fund will eventually decrease.

A contribution of the present paper is to show that, once the actuarial cost per yearof-service criterion is adopted, a reform of pensions is no longer a zero-sum game. If that were the case, any attempt to reform would lead to inevitable conflicts and could not save on public funds without directly hurting the employees' interests. Our reasoning takes place in the space of utilities: workers compare the discounted value of their wages and pension benefits to the disutility of effort. As a consequence, they may agree to retire later, in exchange for a pay raise, and more precisely, for additional steps on the pay scale, reached by those who stay longer in the firm. The government also gains, provided that the actuarial social cost per year of service is decreasing: there is room for negotiation. We show the possibility of such a reform with the help of a simple model. To be more precise, if the information on preferences is complete, and under reasonable parameter configurations, it is possible to design reforms such that, (i), the actuarial cost per year of service of the average agent is reduced; (ii), the utility of public employees does not decrease, and (iii), the budget deficit does not increase.

Our evaluation of this reform uses the actuarial cost per year of service. Our study is based on the knowledge of the RATP personnel compensation schedule and career system, and of the rules used to compute pension benefits before, after and during the transition period induced by the reform. We do not use individual data. The company's pension fund provided us with descriptive data on the pensioners. Some union members and RATP employees provided us with evidence related to company organization and pay. We use public information only, even if, in practice, a large part of the data we exploited is, for understandable reasons, not easily accessible.

The 2008 reform gradually raises the number of years of contribution required for a full-rate pension and introduces a deduction (or penalty) on pension benefits for the employees whose number of years of contribution falls short of the full-pension requirement. In addition, the reform abolishes some generous provisions such as the bonus years, that used to give train drivers the opportunity to retire early. In exchange for these measures hurting the employees' interests, the reform introduced compensatory wage and pension-padding measures.

The 2008 reform sets up a permanent regime that applies only to employees hired after January 1, 2009. This permanent regime is hereafter called the ex post regime and we show that it is likely to save some money. This is the sign that the reform is based on a number of sound principles, but the assessment exercise becomes more complicated, and the conclusions more negative, if we pay attention to the provisions that create a very long transition period. Indeed, from 2012 on, the transition regime, called interim regime, applies to all the employees hired before January 1, 2009!

Then, a national reform act, passed in November 2010, raised the minimum age for retirement with a full pension in the public sector. The sequential enforcement and combination of the 2008 and 2010 pension acts is a source of complexity. Because of the national reform enacted in 2010, the interim period must itself be divided into 2 subperiods. The employees born before 1967 belong to a sub-regime that we shall call interim a: they will still enjoy most of the special rights of the pre-reform regime. The employees born after 
1972 are governed by the rules of a second sub-regime that we call interim $b$ : they will be forced to accept deductions from their pension benefits in case of early retirement; they will no longer have the right to retire at 50, but will still be entitled to bonus years. To sum up, the reform will really start to be enforced when all the employees that were already active in the company in 2008 will have retired.

Granting compensatory measures in exchange for longer careers may be the right policy, but the interim a regime increases the actuarial cost per agent and per year of service, whichever the seniority of the employee at the moment of retirement. The interim $b$ rules should provide incentives to delay retirement and lead to some savings, but not before 2024. Since the number of agents falling under the interim a rules is larger, on average, the interim regime is going to increase social costs. Yet, as already suggested above, the reform has not completely failed, for it should end up reducing the actuarial cost per year of service, albeit in a rather distant future.

The analysis shows that the government "bought" from the oldest employees the right to enact a reform that will apply to the youngest workers. A simple rule would have been to require that the actuarial costs per year of service do not increase during the transition period. This rule can be called "conservative grandfathering", namely, protecting the rights of the oldest workers during a given period of time — to be determined -, without granting them additional entitlements that increase the public burden and, to say the least, pose the embarrassing question of intergenerational equity.

Pensions have been studied by economists in many countries. Feldstein (1974), Burtless (1986), Gustman and Steimeier (1986), Stock and Wise (1990) among many other authors, wrote pioneering papers on the topic. Later contributions are due to, e.g., Rust and Phelan (1997), French (2005), Coile and Gruber (2007), Blau (2008), and Hairault et al. (2010). Pension and Social Security reform have been widely discussed; see Diamond (2002), Barr and Diamond (2008), among many other contributions. The retirement benefits of US state and municipal employees is the subject of a 2014 special issue of the Journal of Public Economics. Different contributions address the issue of designing optimal compensation and retirement schedules for public sector employees; see for instance, Beshears et al. (2014), Clark et al. (2014). Chalmers et al. (2014) study the impact of defined benefit versus defined contribution pension plans on retirement choices, as well as Novy-Marx and Rauh (2014), who investigate the possibility of linking retirement benefits to the investment performance of pension plans. Glaeser and Ponzetto (2014) emphasize the interplay of local and state levels in the design of public pension schemes. ${ }^{7}$

In what follows, Section 2 presents the theoretical model underlying our analysis of the reform. We justify the choice of the actuarial cost per year of service and show that, provided that the latter is decreasing, a Pareto improving reform is feasible. Section 3 is devoted to the description of institutional details that are necessary to understand the reform. Section 4 presents our case study, that is, a quantitative analysis of the Paris subway pension reform.

\footnotetext{
${ }^{7}$ The French case has been, for many years, the subject of various reports of the Pensions Advisory Council (the COR or conseil d'orientation des retraites), an independent body in charge of studies on pensions, placed under the aegis of the Prime Minister. Among recent contributions, see also Bozio and Piketty (2008). To the best of our knowledge, the present article is the first attempt at evaluating the RATP 2008 pension reform with quantitative economic methods.
} 
We compute the actuarial cost per year of service of a subway driver and use this result to formulate an assessment of the reform.

\section{A model of pension reform and individual choice of the retirement age}

To appraise the benefits and costs of the reform, we need a model predicting individual choices of the retirement year. We first discuss the conditions under which the actuarial cost per year of service is a valid criterion. We then show, using a simple theoretical model, that it is possible to reach an agreement under the terms of which employee compensation and length of service are increased and that simultaneously decreases the actuarial cost per year of service.

\subsection{The actuarial cost per year of service}

Consider a large firm whose personnel enjoy lifetime employment and contribute to a payas-you-go pension fund. Assuming constant returns to the labor input, the ratio of total net wages to total output is a measure of the labor unit cost. Since the firm and the pension fund form a consolidated unit, a more accurate indicator is the total expected and discounted sum of wages and pensions, divided by the number of employees and by the employee's length of service. This provides a measure of the cost of the implicit commitments to offer lifelong careers to workers and of future pension liabilities. This indicator is relevant in a stationary regime in which the seniors who are leaving are replaced with new recruits in equal number. It is all the more relevant if the discount rate chosen by the consolidated unit reflects the interest rate at which it can lend or borrow money on financial markets.

Viewing the firm and its pension fund as a single entity, a reasonable social objective is to maximize the social surplus associated with the firm's production activity. In the case of a public service like the Paris metro, this social surplus is approximated by the firm's profit, if the price of a metro ticket is equated with the average willingness to pay for a metro ride. For the sake of simplicity, let us assume that the firm's output and the train driver's productivity are both constant ${ }^{8}$. If we assume that the social value attached to production, maintenance and depreciation costs are also constant, then, social surplus maximization implies minimization of the social cost per driver. The goal is to lighten the burden of French taxpayers, whose contributions directly finance public transportation. This is an intuitive justification for the measure of cost used below. Considering the entire life cycle of a train driver, we compute the expected total sum of discounted real net wages and pension benefits, divided by the length of service. This ratio reflects the social cost of a train driver, available during a year, in a stationary state.

\footnotetext{
${ }^{8}$ Suppose that the metro network is operated in the same way and that each train driver supplies the same number of trips per unit of time on a given line, during a long period of time. This is not exactly true since a new metro line has recently been build, other lines have been lengthened and some of the lines are now completely automated so that the train driver's average productivity has increased in the long run. But these changes are slow.
} 
As for the discount rate, we shall retain a default-free interest rate. The State implicitly guarantees the debts of the company and of its pension fund. The government directly subsidizes the RATP pension system. In practice, a long-term average of rates on long-term government bonds seems appropriate as a first approximation. In fact, the exact value of the interest rate doesn't matter much: we will allow that discount rate to vary in a reasonable range to discuss sensitivity to discounting.

\subsection{A simple economic model}

We consider a population of identical individuals beginning their career at time $t=0$. Continuous time is adopted for convenience; we will consider discrete time in the case study that follows. As explained above, the career of a RATP train driver is completely governed by seniority. Hence, it is deterministic. Let $w(t)$ be the gross real wage of an individual with seniority $t$ in the firm. We assume that wages and pension benefits are specified in real terms. Put differently, the firm and its employees anticipate a perfect indexation on inflation. The real wage function has, for simplicity, the following linear specification, $w(t)=w_{0}+w_{1} t$, where $w_{0}$ and $w_{1}$ are positive parameters. We also suppose that the probability of death at time $t$ is exponentially distributed with parameter $\delta$. The survival probability at time $t$ is then $e^{-\delta t}$. The discount rate, common to the firm and the employees, is denoted $r$. The discounted expected value of the wage, paid at date $t$, but discounted at date 0 is given by $w(t) e^{-(r+\delta) t}$. Let us define $s=r+\delta$. Let now $\tau$ be the retirement time (this is also the seniority of the agent at the moment of retirement). The discounted sum of wages of an agent retiring at $\tau$ can be expressed as follows:

$$
W(\tau, s)=\int_{0}^{\tau} w(t) e^{-s t} d t .
$$

Let us denote $R$ the real pension benefit paid to the agent until he passes away. This amount is constant over time from the retirement date $\tau$ on. The agent leaving with seniority $\tau$ and receiving a pension $R$ has the following discounted real expected social cost,

$$
C(\tau, R)=(1-k) W(\tau, s)+e^{-s \tau} \frac{R}{s}
$$

where $k$ is the rate of contributions collected on wages.

The employees are assumed risk neutral and incur an instantaneous labor disutility denoted $\theta \gamma(t)$, where $\theta$ is a positive parameter, and $\gamma(t)$ is increasing and differentiable with respect to the length of service (seniority) $t$. The instantaneous utility of a working agent is defined as follows,

$$
u(t)=(1-k) w(t)-\theta \gamma(t)
$$

The instantaneous utility of a retiree is $u(t)=R$. The expected utility discounted at date 0 is defined by: $U(\tau, R, \theta)=\int_{0}^{\infty} u(t) e^{-s t} d t$. This can be rewritten as,

$$
U(\tau, R, \theta)=C(\tau, R)-\Gamma(\tau, \theta)
$$

where $\Gamma$ represents the total discounted disutility of labor, that is,

$$
\Gamma(\tau, \theta)=\theta \int_{0}^{\tau} \gamma(t) e^{-s t} d t
$$


For illustrative purposes, we consider the following simple form for the labor disutility: $\gamma(t)=e^{g t}$. Assuming $g>s$ guarantees that $\Gamma$ is convex with respect to the length of service, which seems reasonable.

Turning to the pension fund's budget constraint, we assume the ideal situation of a stationary state. The firm has hired the same number of agents per unit of time, in the past, and since its beginning. The agents, all identical, retire with the same seniority $\tau$ and receive the same pension benefit $R$. The per capita expected value of the pension benefit is given by $\int_{\tau}^{\infty} R e^{-\delta t} d t=(R / \delta) e^{-\delta \tau}$.

The pension fund is supposed to receive a per capita subsidy $B$, assumed constant over time. The per capita contributions collected on active employees with seniority between 0 and $\tau$ is $k W(\tau, \delta)$. At any instant, the pension fund's budget constraint can be written,

$$
\frac{R e^{-\delta \tau}}{\delta} \leq B+k W(\tau, \delta)
$$

In a stationary regime, the budget constraint can be expressed as an upper bound on the pension benefit, that is, $R \leq \bar{R}(\tau, \delta)$, where by definition,

$$
\bar{R}(\tau, \delta)=\delta e^{\delta \tau}(k W(\tau, \delta)+B) .
$$

We are now able to study different pension formulas. We compute the cost and the utility of an employee and test feasibility with the budget constraint. The classical formula prevailing in the French public sector used to give $\rho=2$ of the final gross wage per year of contribution. In the case of a linear career, these provisions yield a quadratic formula, denoted $R_{q}$,

$$
R_{q}(\tau)=(\rho \tau)\left(w_{0}+w_{1} \tau\right) .
$$

The discounted total cost of an employee whose career is $w(t)$ and whose pension benefit is $R_{q}(\tau)$ is given by $C\left(\tau, R_{q}(\tau)\right)$. Figure 1 depicts this curve in a numerical example ${ }^{9}$, where the wage is an affine function of time. The curve is quasi-concave and reaches a maximum around $\tau=50$. To minimize this cost, the employees would have to be fired after 1 year of service! The appropriate measure of cost is of course the ratio $C / \tau$, the cost per year of service. Figure 2 represents the function $C\left(\tau, R_{q}(\tau)\right) / \tau$, which is decreasing and convex in the illustrative example considered. The utility function, $U(\tau, R, \theta)$ with $R$ fixed is decreasing. If the employee could enjoy $R$ whatever the contribution length, he would quit after one year of service. This is misleading since with the formula $R_{q}(\tau)$, an employee has to contribute 38 years to be entitled to a $75 \%$ replacement rate of his last gross wage. Figure 3 displays $U\left(\tau, R_{q}(\tau), \theta\right)$, which is quasi-concave and reaches its global maximum at $\tau=39$. Thus, in the example, an employee subjected to the traditional public sector rules would prefer to work and contribute during 39 years. The budget constraint, i.e., $\bar{R}(\tau, \delta)$, is plotted on Figure 4 as a function of $\tau$. The values of the pension $R$ that do not generate a deficit in the stationary regime lie below the curve, which is increasing and convex. The units of the vertical axis have been divided by 12 for simplicity and read as net and real monthly pension benefits (in euros). We now focus on the utility $U$ and the cost per year of service, $C / \tau$,

\footnotetext{
${ }^{9}$ The figures below have been computed with the following numerical values: $r=\log (1.02)=0.0198$; $\delta=0.05 ; k=0.33 ; w_{0}=12 \times 1333 ; w_{1}=12 \times 40 ; \rho=0.02 ; R=12 \times 2165 ; \theta=250 ; \gamma=0.085 ; B=0$.
} 
Figure 1: Discounted total cost of an employee

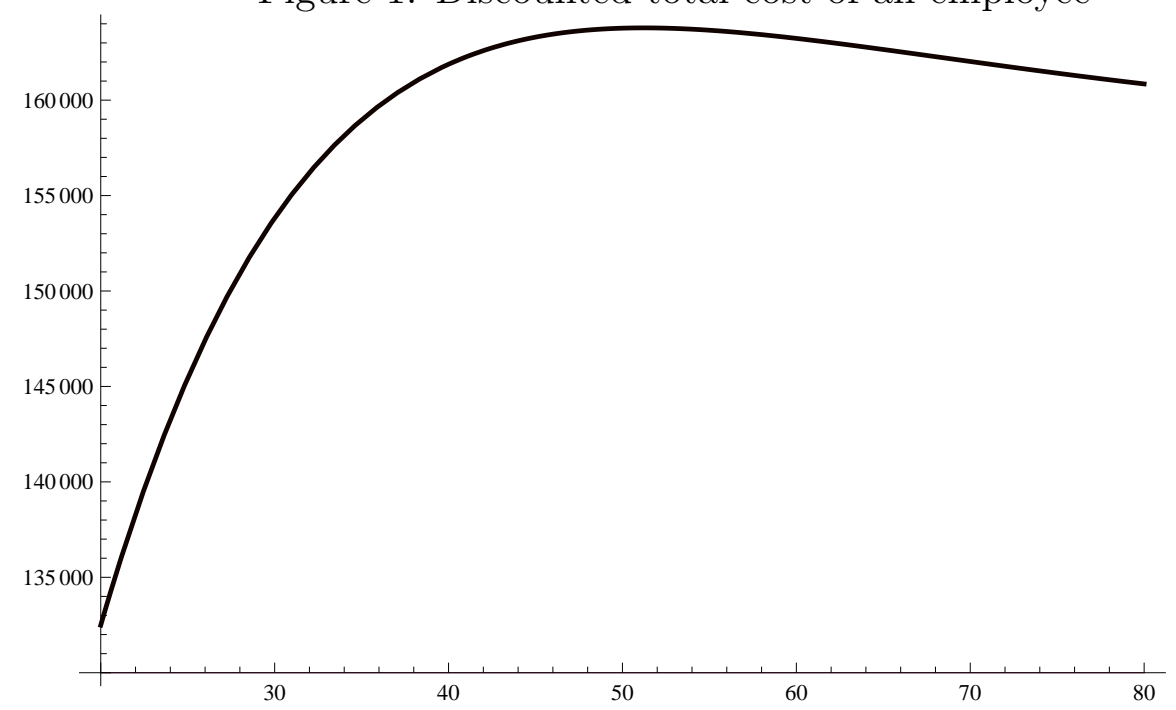

Figure 2: Actuarial cost per year of service $C\left(\tau, R_{q}(\tau)\right) / \tau$

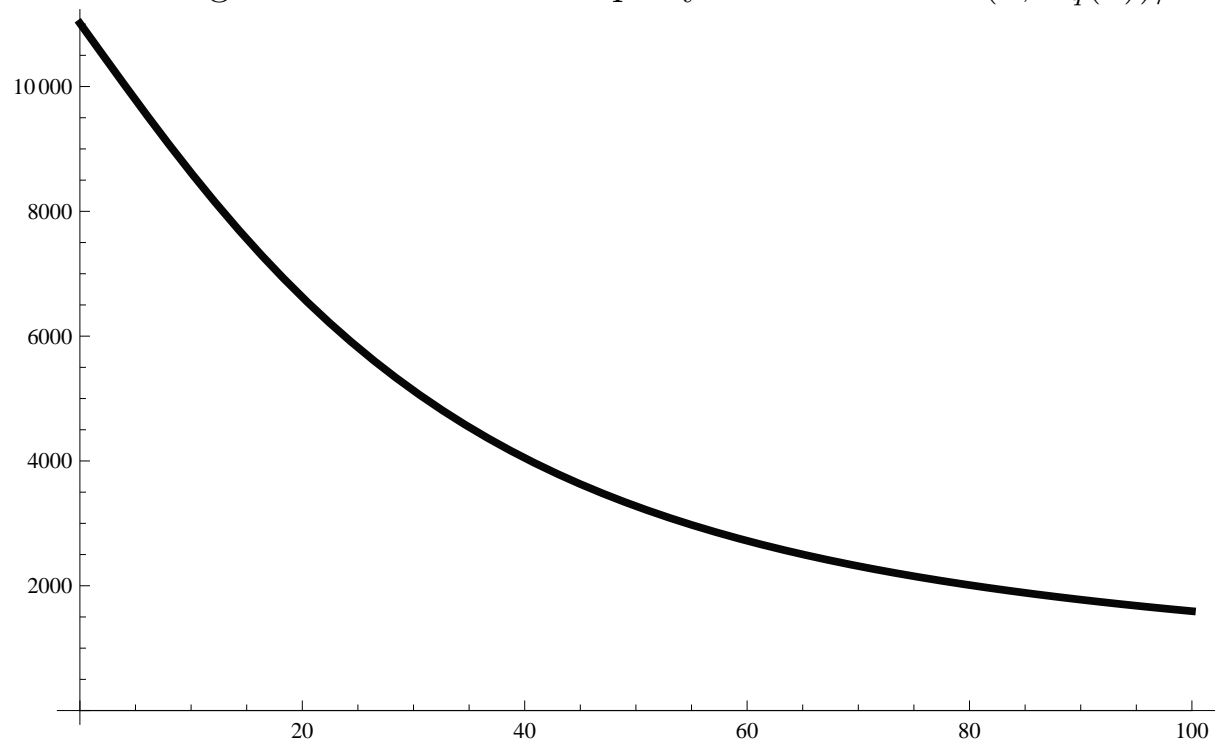


Figure 3: Utility $U\left(\tau, R_{q}(\tau), \theta\right)$

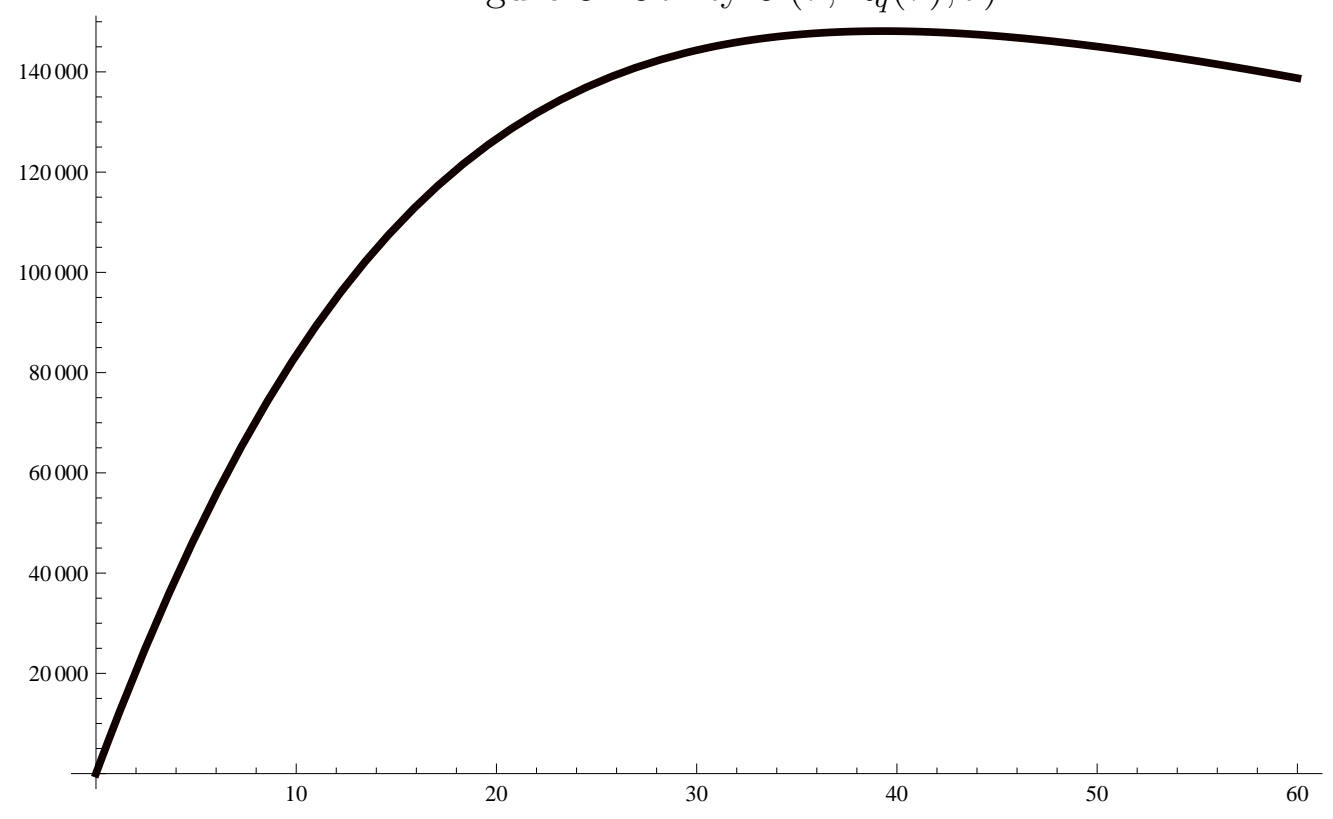

Figure 4: Budget constraint $\bar{R}(\tau, \delta)$

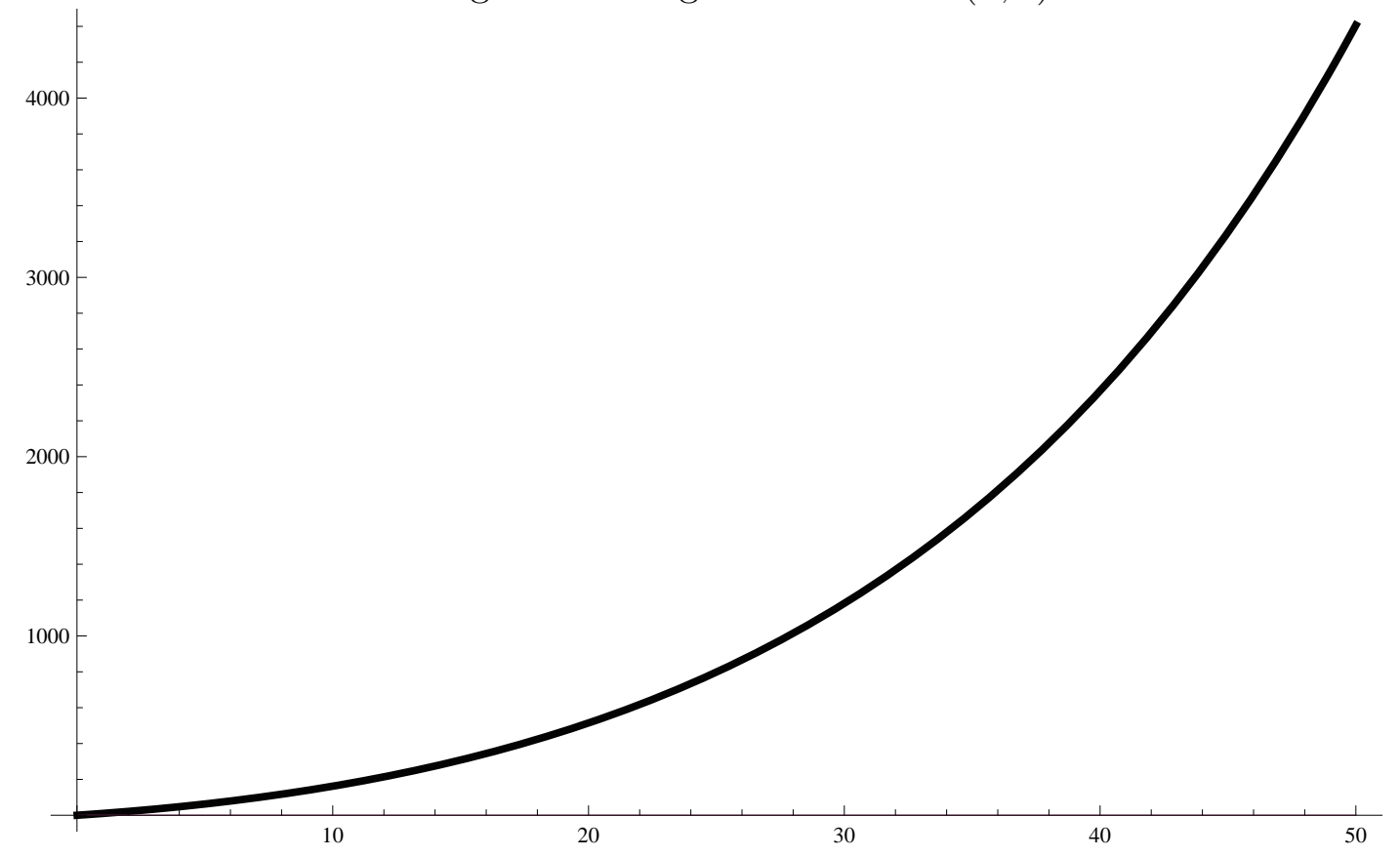


Figure 5: Utility subject to budget constraint $U(\tau, \bar{R}(\tau, \delta), \theta)$

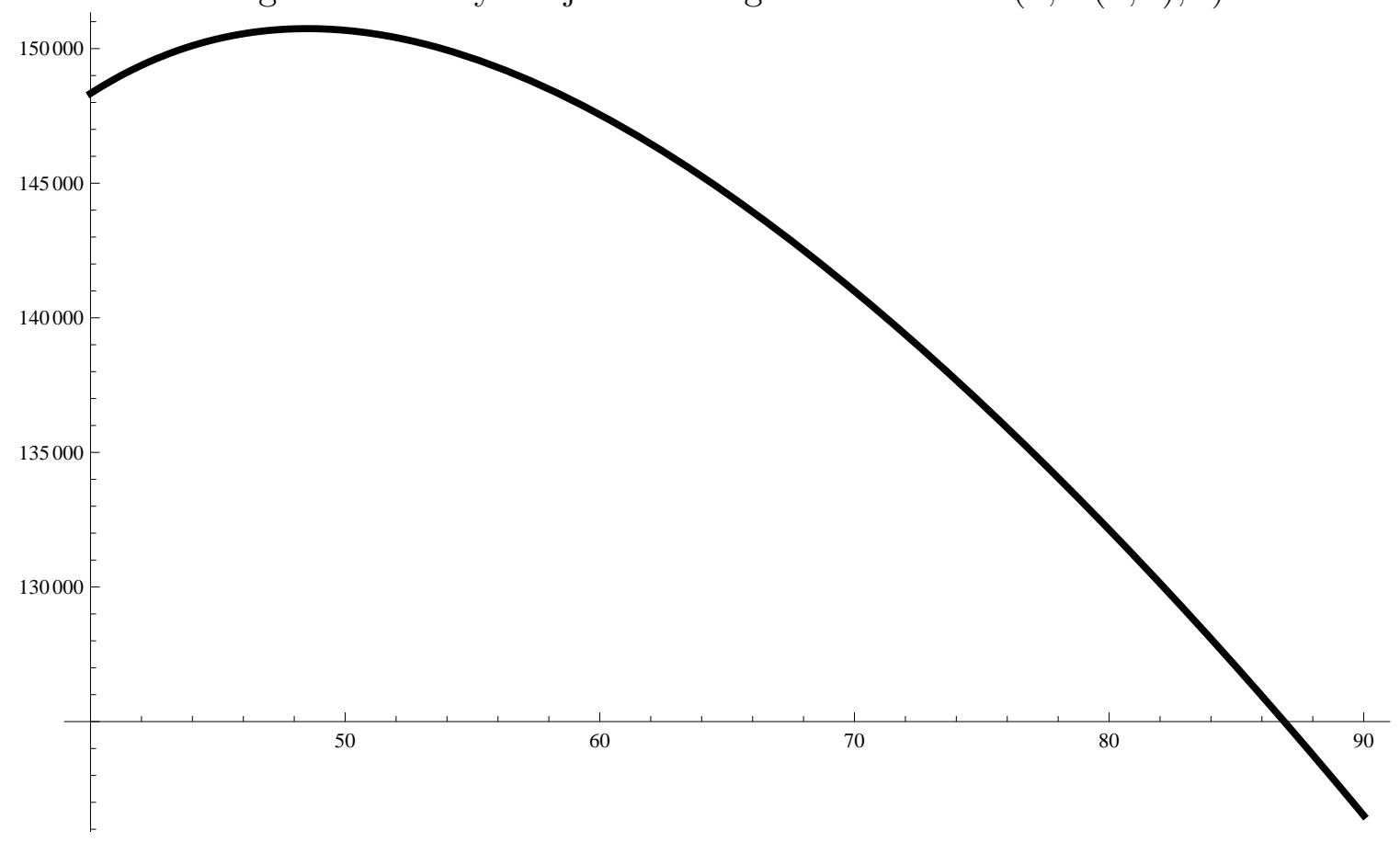

of an agent whose pension benefit exactly balances the budget, that is, when $R=\bar{R}(\tau, \delta)$. Figure 5 represents the curve $U(\tau, \bar{R}(\tau, \delta), \theta)$ in the $(\tau, U)$ plane. This curve is quasi-concave and reaches a maximum for a seniority of 48 years and a half. If we compare this curve with that of Figure 3, which is computed with the help of the classical formula for public sector pensions, we can see that the agent is willing to work longer under the budget constraint (without any subsidy), since the maximum on Figure 3 is reached for 30 years; and in fact, the utility level at the maximum, on Figure 5, i.e., 150, 000 units of utility, is higher than the level reached in Figure 3, i.e., 148, 000 units of utility. These welfare level comparisons are relevant since utility units are real euros discounted at the same date 0 , and the parameters of the utility function are the same on the two figures.

The next step in the reasoning is to check whether there is room for a successful reform, computing the discounted expected cost per year of service subject to the budget constraint. Figure 6 gives the shape of the curve $C(\tau, \bar{R}(\tau, \delta)) / \tau$, in the $(\tau, C / \tau)$ plane. The cost curve is decreasing for contribution lengths ranging from 20 years to 60 years. This suggests that the State can negotiate an agreement according to which the length of service is increased - yielding an increased final wage and pension benefit -, the cost per year of service is decreasing at the same time and without increasing the deficit. Such an arrangement would enhance efficiency. In other words, there is a room for a Pareto-improving reform. To see this, we plot the indifference curves of our representative employee in the numerical example. First of all, an indifference curve associated with a level $u_{0}$, namely $U(\tau, R, \theta)=u_{0}$, can equivalently be rewritten as a curve $R=\tilde{R}\left(\tau ; \theta, u_{0}\right)$ in the $(\tau, R)$ plane, with

$$
\tilde{R}\left(\tau ; \theta, u_{0}\right)=s e^{s \tau}\left[u_{0}+\Gamma(\tau, \theta)-(1-k) W(\tau, s)\right] .
$$


Figure 6: Actuarial cost per year of service, $C(\tau, \bar{R}(\tau, \delta)) / \tau$

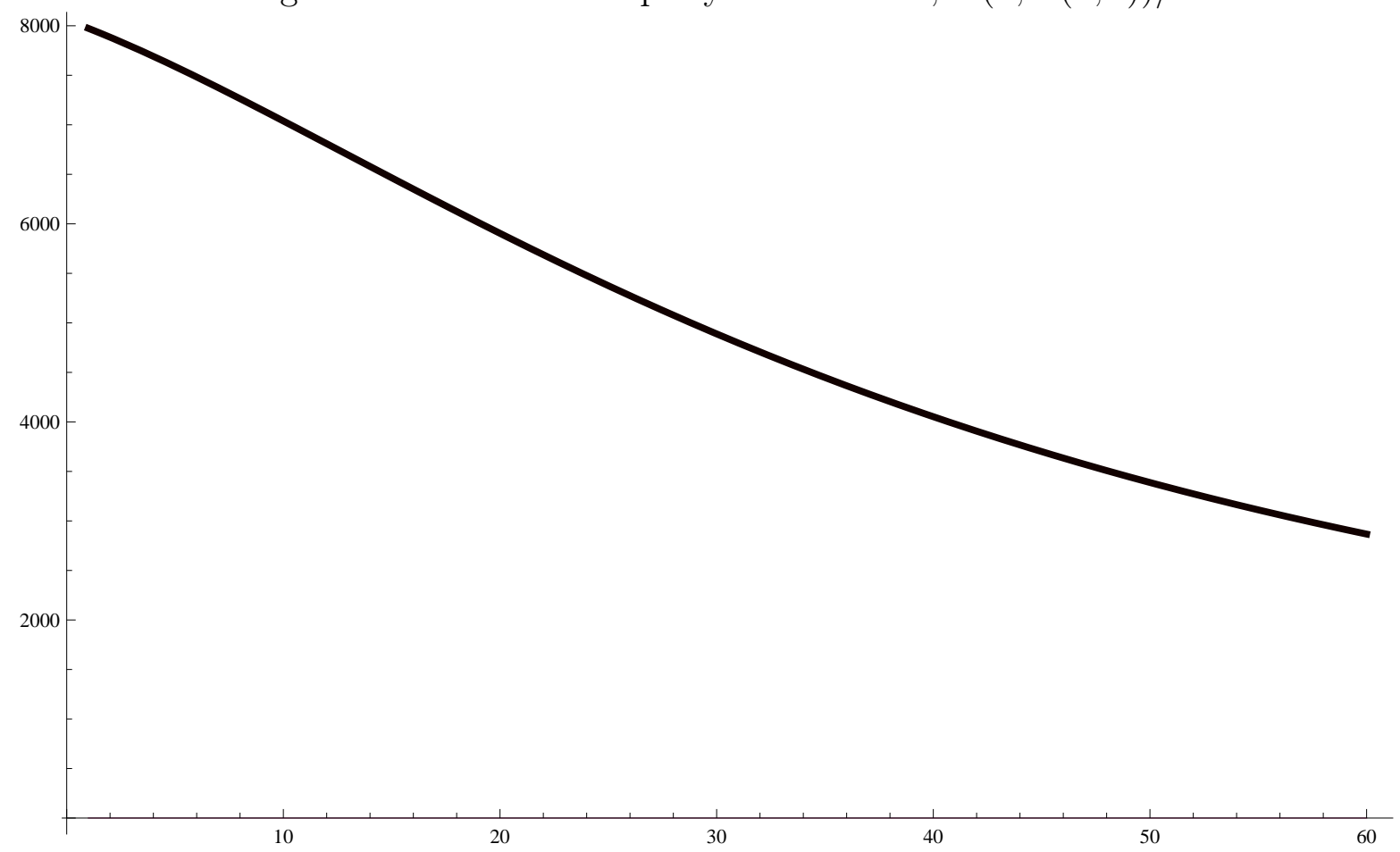

Figure 7 depicts a set of indifference curves, obtained by letting $u_{0}$ vary from 128, 000 to 220,000 . On the vertical axis, pension benefits are in monthly amounts.

These preferences become non convex for small amounts of pension benefit $R$ and large values of seniority $\tau$. Yet, for reasonable values, preferences are convex and the marginal rate of substitution between $\tau$ and $R$ is negative. The slope of the indifference curve is given by the expression,

$$
\frac{\partial \tilde{R}}{\partial \tau}=s[\theta \gamma(\tau)-(1-k) w(\tau)]+s \tilde{R}\left(\tau ; \theta, u_{0}\right)
$$

It is always positive for $\theta$ and $u_{0}$ large enough, and for reasonable values for $\tau$ (here, for $\tau$ between 0 and 50 years), and for $u_{0} \geq 140000$.

We show, in our illustrative example, that it is possible, under the budget constraint, to decrease the agent's discounted cost per year of service by means of an increase of her length of contribution and her pension benefit, in such a way that utility is not decreased. Figure 8 illustrates the situation. The indifference curve $R=\tilde{R}\left(\tau ; \theta, u_{0}\right)$ and the budget constraint $R=\bar{R}(\tau, \delta)$ both cut the constant $R=R_{0}=2074$ at the same point $\left(\tau_{0}, R_{0}\right)$.

1. The benefit that satisfies the budget constraint in the example is $R_{0}=2074$ euros per month when the employees contribute during $\tau_{0}=38$ years. The associated utility level is $u_{0}=146939$.

2. Given the indifference curve $R=\tilde{R}\left(\tau ; \theta, u_{0}\right)$, the marginal rate of substitution evaluated at $\left(\tau_{0}, R_{0}\right)$, is such that the employee requires an increase of 75 euros per month to compensate for an increase of the contribution length from 38 to 39 years.

3. At point $\left(\tau_{0}, R_{0}\right)$, the respective slopes of the budget constraint and of the in- 
Figure 7: Indifference curves

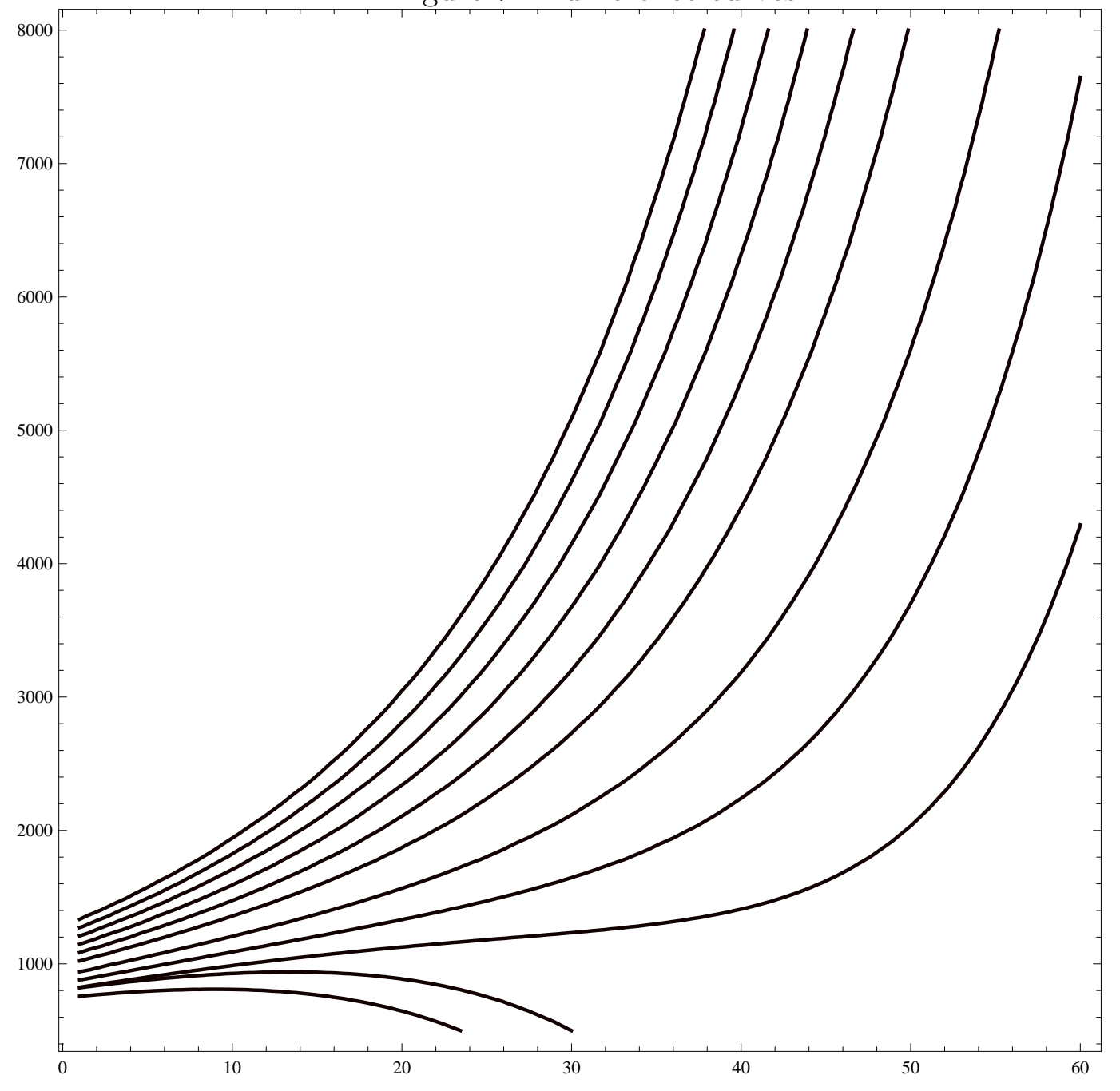


Figure 8: Indifference curve $R=\tilde{R}\left(\tau ; \theta, u_{0}\right)$ (solid) and budget constraint $R=\bar{R}(\tau, \delta)$ (dashed)

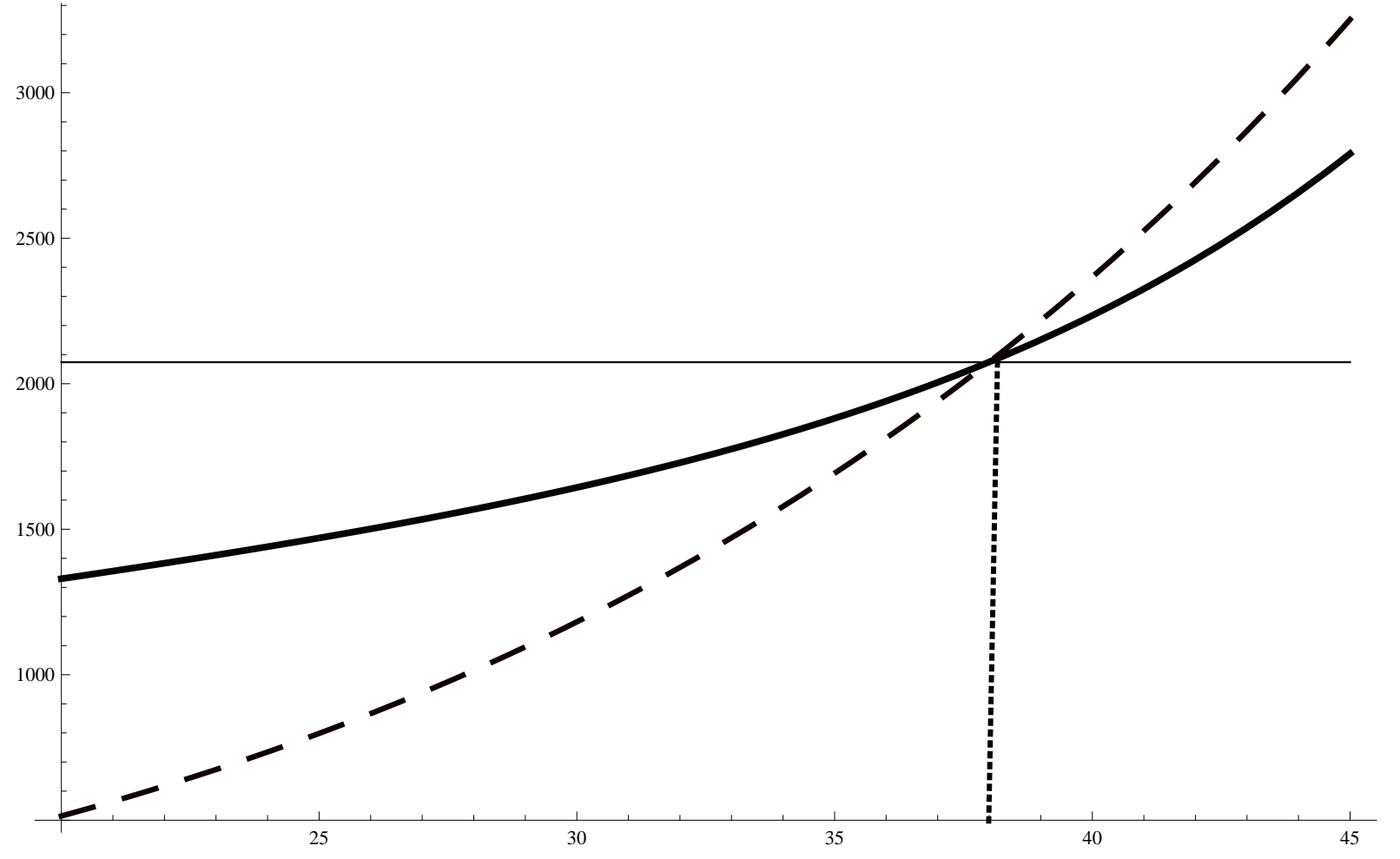


difference curve are such that $\partial \bar{R} / \partial \tau>\partial \tilde{R} / \partial \tau$. This suggests that the maximal pension benefit compatible with the budget constraint increases faster than the amount needed to compensate the employee for a longer length of service.

4. It is possible to find $\Delta R>0$ and $\Delta \tau>0$ such that the budget constraint is satisfied and the utility is simultaneously higher than $u_{0}$, or $\Delta U>0$. At the same time, the cost per year of service, $C(\tau, R(\tau, \delta)) / \tau$, decreases strictly. With $\tau_{1}=\tau_{0}+\Delta \tau$, and $R_{1}=R_{0}+\Delta R$, we have

$$
\frac{C\left(\tau_{1}, R_{1}\right)}{\tau_{1}}<\frac{C\left(\tau_{1}, \bar{R}\left(\tau_{1}, \delta\right)\right)}{\tau_{1}}<\frac{C\left(\tau_{0}, R_{0}\right)}{\tau_{0}},
$$

and

$$
\tilde{R}\left(\tau_{1} ; \theta, u_{0}\right)<R_{1}<\bar{R}\left(\tau_{1}, \delta\right) .
$$

The analysis of the example shows that a Pareto-improving reform is possible, provided that $C(\tau, \bar{R}(\tau, \delta)) / \tau$ is decreasing, and provided that the marginal rate of substitution, $\partial \widetilde{R} / \partial \tau$, is not too large. Thus, there is scope for negotiation in the model we are considering. Designing a reform that increases social welfare does not lead to a conflict situation in which public sector employees would necessarily end up being worse off.

The above approach can be generalized to study first-best optima with multiple types of employees. For instance, employees may differ in terms of their labor disutility. Employee heterogeneity can be represented by a probability distribution of the types $\theta$. However, the government does not observe the agents' labor disutilities, and thus doesn't know how much to offer as a compensation for additional years of work.

If types are not observable by the public planner, the analysis of the optimal reform in an incomplete information setting is a non-trivial optimal-taxation exercise. Any retirement formula that combines a pension benefit $R(\tau)$ with the choice of seniority at the moment of retirement $\tau$ will induce self-selection by the agents. Moreover, taking the participation constraint of employees into account is another serious difficulty.

The strict protection of vested interests requires that, under the reform, none of the agents should end up with a utility smaller than the level reached in the status quo ante. But a reform is possible since the public authority can "buy" an increase in the length of service. Mechanism design theory tells us that, under asymmetric information, a second-best optimum may be inefficient if unanimity is required. Because agents with small disutilities may report a high value of this parameter, a significant amount of resources may be required to compensate agents for the revelation of their unobserved disutility of effort. ${ }^{10}$ Thus, unanimous approval is a costly requirement, but gathering more than $50 \%$ of the employees' votes would be enough to support an agreement. In principle, it is possible to negotiate a reform that is Pareto-improving, even if informational asymmetries hamper the bargaining process to a certain extent. These difficult questions are beyond the scope of the present paper.

\footnotetext{
${ }^{10}$ In addition, the rate of inefficiency typically increases with the number of agents (on these points, see Rob (1989), Mailath and Postlewaite (1990)).
} 


\subsection{Empirical implementation}

In the empirical model, time is discrete and a period $t$ represents a year. We assume that life does not last more than a hundred years $(T=100)$. We use life tables to compute expectations. We give below the expression for the value of a career in the special case where the agent is risk-neutral. The details are given in Appendix A.

The career value at age $t_{1}$, for an agent hired at age $t_{0}$, and retiring with seniority $\tau$ can be expressed as the expected utility of a risk-neutral employee with a zero disutility of labor, namely,

$$
C\left(t_{0}, t_{1}, \tau\right)=\sum_{t=t_{1}}^{\tau+t_{0}-1} \frac{s(t)}{s\left(t_{1}\right)} \frac{w\left(t-t_{0}\right)}{(1+r)^{t-t_{1}}}+\sum_{t=\tau+t_{0}}^{T} \frac{s(t)}{s\left(t_{1}\right)} \frac{R\left(\tau, \tau+t_{0}\right)}{(1+r)^{t-t_{1}}},
$$

where $s(t)$ denotes the probability of survival at $t$, and where $T$ is such that $s(T)=0$.

The maximization of the expected career value yields a decision function, denoted $d^{*}$, which gives seniority at the moment of retirement as a function of the agent's disutility type $\theta$ and of the age $t_{0}$ at which the agent started her career, i.e., $\tau=d^{*}\left(t_{0}, \theta\right)$. Let $m(\tau)$ denote the average probability of retiring with seniority $\tau$.

Letting $\lambda\left(t_{0} \mid \tau\right)$ be the probability of having started a career at age $t_{0}$, given that seniority is $\tau$ at the moment of retirement, we can define the average total cost of an agent retiring with seniority $\tau$ as follows,

$$
v(\tau)=\sum_{t_{0}} C\left(t_{0}, t_{0}, \tau\right) \lambda\left(t_{0} \mid \tau\right)
$$

and this agent's social cost per year of service is defined as $c(\tau)=v(\tau) / \tau$.

A benevolent social planner should choose a general wage schedule $w($.$) and a pen-$ sion benefit formula $R($.$) that jointly minimize the average social cost per year of service,$ $\Sigma_{\tau} m(\tau) c(\tau)$, subject to a number of constraints.

Monetary incentives to defer retirement will affect the probability $m(\tau)$ in the right direction. Some individuals at least will decide to delay retirement. This will in turn cause a reduction of the average social cost per year of service $\Sigma m(\tau) c(\tau)$. If decision functions were inelastic, the reform would fail. But this would take very special train drivers for whom retirement must, at any price, occur at the age of 52, which is not really plausible.

There would exist little room to design a Pareto-improving reform if labor disutilities $\theta$ were very large. This could happen if the labor disutility function increased very quickly after age 50. Train drivers might have decided to retire early because they planned to combine pension benefits with the income of another activity. The sources of this opportunity cost may be the legal combination of pension benefits and labor income or domestic production in the informal sector. ${ }^{11}$ Asking some agents to work longer would force them to forgo income and would cause opposition to change. In practice, post-retirement labor seems to be underdeveloped among blue collars. ${ }^{12}$ But we do not know much about the use of time

\footnotetext{
${ }^{11}$ The combination of pension benefits and income from post retirement labor has been recently liberalized. In particular, since 2009, RATP employees can work during retirement without restrictions, provided that they effectively retired and that they contributed enough to get a full-rate pension.

${ }^{12}$ See Coeffic (1999).
} 
in the population of recently retired employees. It seems reasonable to admit that $x \%$ of the agents will oppose any reform because, to induce consent, the company would have to increase their salary at unacceptable values. An " $x \%$ optimal reform" would buy the best decisions to postpone retirement while hurting less than $x \%$ of the agents, in a context where the social costs per year of service are decreasing.

\section{Quantitative analysis of the reform}

In order to have an assessment of the reform, let us first give a brief description of the pension schemes before and after the 2008 and 2010 acts were passed. We provide a longer description of institutional details in Appendix B.

\subsection{The pension scheme before and after the reform}

Before the reform, to be entitled to the company's pension scheme, an employee had to complete a minimal number of years of service in the firm and reached the eligibility age. Difficult labor conditions, such as night work and special timetables, allowed for early retirement. Pension benefits are proportional to the length of service and to the last salary.

Before the reform, a full-rate pension could be claimed after 37.5 years of career and would amount to $75 \%$ of the employee's final gross salary.

The 2008 reform introduced a number of changes. First, the contribution length required for a full-rate benefit was gradually increased from 37.5 years to 40 years as of 2016 .

Second, measures that provide incentives to postpone the effective retirement age were adopted: a penalty (respectively a premium) reduces (resp. increases) the pension rate when the contribution length is smaller (resp. larger) than the requirement for a full pension. Train drivers were benefiting from the so-called bonus years: typically one additional year of contribution for 5 years of service. A worker could retire after 25 years of service, at age 50 , as if he had contributed during 30 years. It is striking that these bonus years are eliminated for agents hired after January 1, 2009. Moreover, as of January 1, 2009, pensions will no longer be indexed to company wages, but will follow the evolution of the consumer price index instead. Finally, a number of pay-raise and pension-padding measures were granted.

The 2010 act reforming all civil service pensions, introduces a further 2-year increase in the minimum retirement age and in the minimal length of service.

We computed the net compensation (see Appendix $\mathrm{C}$ for details) and the pension benefit attached to each position that will be held by a train driver during his career. Then we calculated the value of the driver's career and some indicators of the pension-scheme return in three situations: before the reform, after the reform and during the interim period.

Let us first describe the three situations under consideration and recall the parameters that apply to them.

1. The ex ante situation takes place just before the reform. The bonus year system applies. Agents can retire at the age of 50 with a minimal service of 25 years; the length of service required for a full pension is 37.5 years and the accrual rate is $2 \%$. There is no penalty (resp. premium) if the employee retires sooner (resp. later) than 37.5 years. The contribution rate borne by the employees and the employer are respectively $12 \%$ and $18 \%$. 
Figure 9: Ex ante and ex post career profiles in 2010 euros

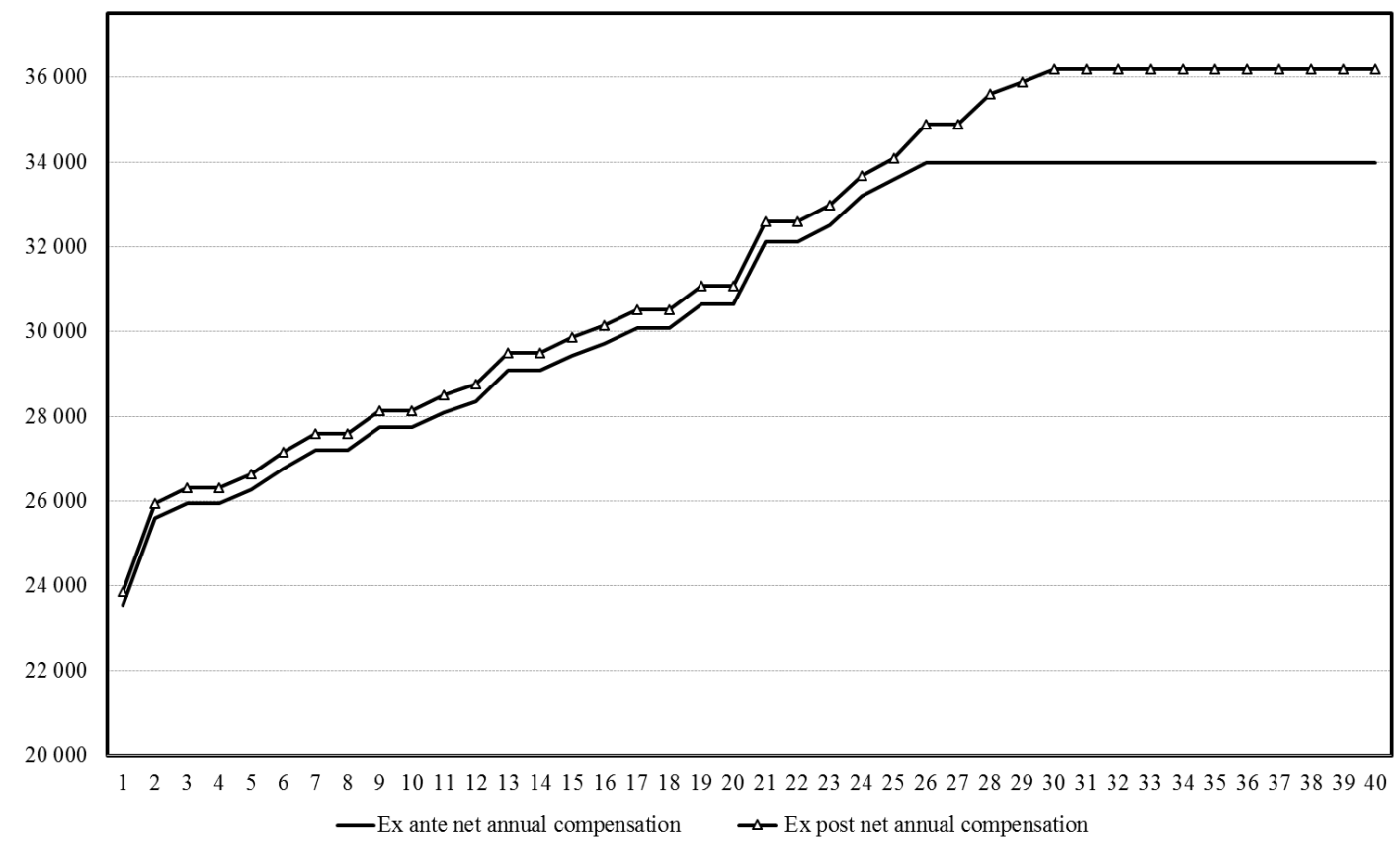

Lastly, the firm has granted a $2.4 \%$ wage increase to offset the 2006 increase in contribution rates.

2. The interim situation applies to all the agents hired before January 2009. The workers are entitled to additional steps in the wage schedule and to the pay increases introduced by the 2008 reform; early retirement is now punished, but agents still benefit from the generous bonus-year system.

A more careful description is needed because of the 2010 public pensions act. Agents born before 1967 and after 1972 have to be distinguished.

- The interim a regime applies to workers born before 1967. In this sub-regime, the 2008 reform requirements bearing on the eligibility age, on the minimal length of service, and on contribution rates do not apply.

- The interim $b$ regime applies to agents born after 1972 who will have to serve at least 27 years and reach the age of 52 to be eligible for retirement.

3. The 2008 reform fully applies in the ex post situation. This regime applies to employees hired after January 1, 2009 only. For these agents, the bonus years no longer exist; the minimal retirement age will be 52 and a minimum of 27 years of service will be required. The penalties for early retirement and the new wage-schedule measures are enforced.

We use the general wage schedule of July 2010. This is the last one that about which our information is complete. Figure 9 below plots the take-home compensation profiles as a function of seniority. More precisely, only the ex ante and the ex post profiles are displayed, because the interim and ex post curves differ only after retirement. The two curves describe the evolution of the yearly net compensation over a working period of 40 years. They share 
the same ascending shape which becomes flat at some point in the career. The flat part of the curve begins at the 26th year of service under the ex ante regime and at the 30th year of service under ex post parameters. The difference between the two curves is due to the impact of the additional steps on the wage schedule.

\subsection{The reform provides incentives to postpone retirement}

In the following, our methodology is to study a typical train driver. Hired at the age of 22 , we assume that he works during 30 years and has the right to retire at the age of 52 . We lengthen his career from 30 to 40 years of work in order to capture the consequences of delaying retirement on different indicators of the returns to the pension scheme. We study in turn the internal rate of return of the pension scheme and the expected discounted value of the career in the ex ante, interim and ex post situations.

\subsubsection{The internal rate of return of the RATP pension scheme}

We assume that the agent is hired at age $t_{0}$. Let $Q(t)$ be the total contribution of an agent at age $t$, and $R(\tau)$ the amount of the pension benefit earned at age $t_{0}+\tau$, when the contribution length is $\tau$ years, everything being expressed in constant real euros. The function $R($.$) directly depends on the age at retirement because of the eligibility conditions.$

The internal rate of return, IRR, denoted $\iota$, is the rate at which the contributions would have to be invested to get a payment equivalent to the pension benefit. Using a mortality table, the IRR takes the survival probabilities into account ${ }^{13}$ and solves the following equation,

$$
\sum_{t=t_{0}}^{t_{0}+\tau-1} \frac{s(t) Q(t)}{(1+\iota)^{t}}=\sum_{t=t_{0}+\tau}^{99} \frac{s(t) R(\tau)}{(1+\iota)^{t}} .
$$

Figure 10 shows the IRR in three regimes as a function of the length of service. Under the $e x$ ante rules, the IRR reaches a maximum around $3 \%$ for the shortest career. In this respect, the pre-reform regime generated strong incentives to leave as soon as possible. Under the new parameters, the IRR drops. In the interim $b$ and ex post situations, the IRR is maximal for a length of service equal to 34 years and 35 years, respectively. The interim a IRR curve does not appear on Figure 10, but our calculations show that under the rules of the latter sub-regime, the IRR is always decreasing: it decreases slowly at the beginning and then decreases faster after 31 years of service (this career length coincides with the normal retirement age). 14 We found that the special RATP pension scheme provided riskless returns lying between $1.5 \%$ and $3 \%$ in real terms before the 2008 reform. The mere fact that they are positive in a system which generates deficits tells a lot about its generosity.

\footnotetext{
13 See INED (2011). We used the data relative to men.

${ }^{14}$ The agent that we considered is hired before January 1, 2009, at the age of 22 . When he reaches the minimal retirement age of 50 he has already 28 years of service. Hence, with 31 years of career, he is 53 , which is the normal retirement age.
} 
Figure 10: Internal rates of return

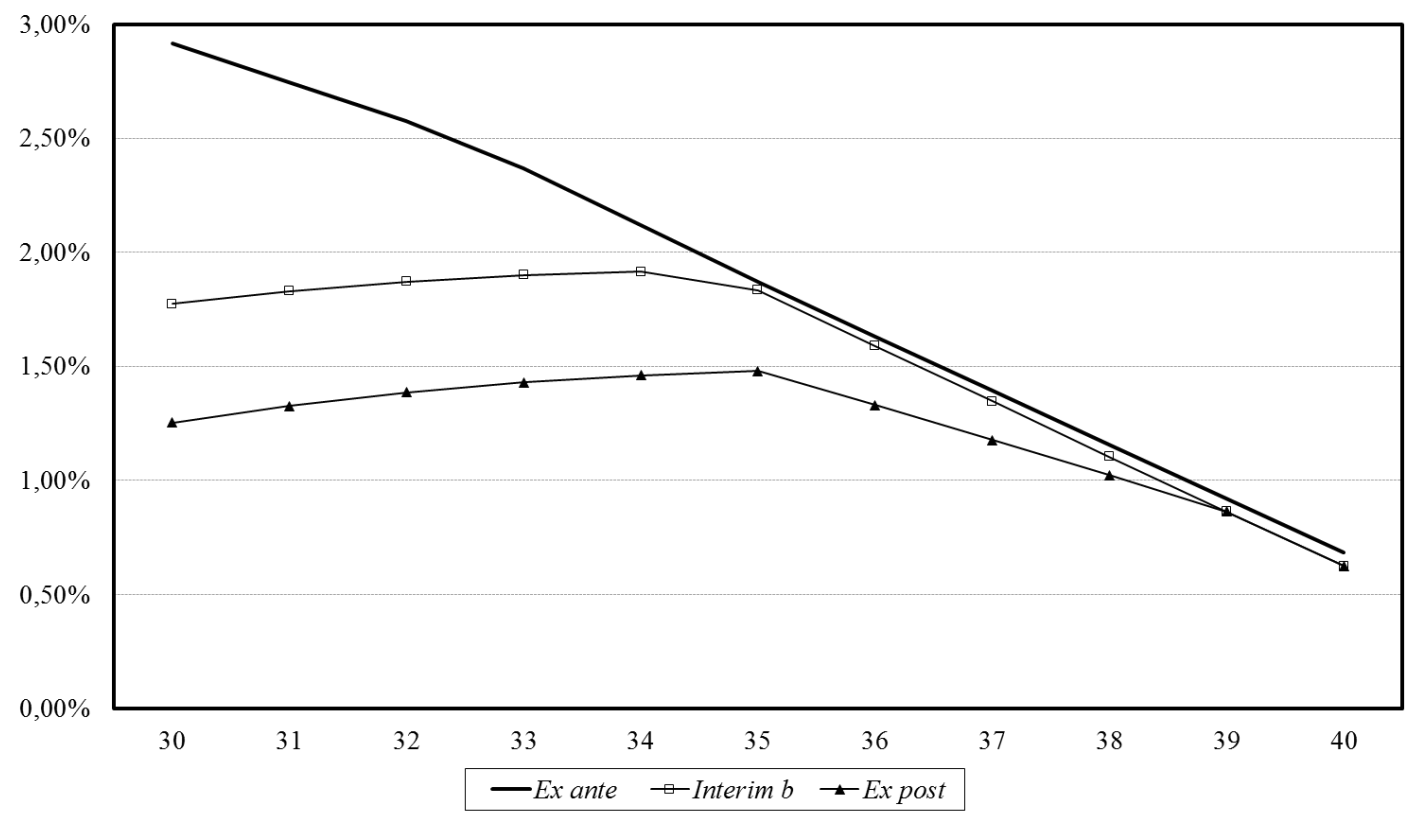

\subsubsection{Discounted value of careers}

Figure 11 represents the expected discounted career value of an agent hired at age $t_{0}=22$, or $C(22,22, \tau)$, allowing $\tau$ to vary between 30 and 40 years. Figure 11 gives the ex ante, interim $b$ and ex post curves for a discount rate $r=3.5 \%$. The values are expressed in real 2010 euros. The value of careers is increased for employees born after 1972 and hired before 2009, provided that they decide to retire with more than 34 years of service. ${ }^{15}$ The jump would be larger if we considered interim a employees since they enjoy more generous conditions. As a consequence, for a large number of train drivers, already working in the firm in 2008, the reform creates substantial opportunities, provided that they accept to work during more than 30 years. It can be shown that the reform raises the marginal value of an additional year in the firm, but we skip the details of these computations since the conclusion would be the same.

\subsection{Will the reform save taxpayers money?}

Figure 12 below displays the discounted social cost per year of service of a train driver in the three situations ex ante, interim $\mathrm{b}$ and ex post, using $r=3.5 \%$. A similar picture is obtained with other reasonable values of the discount rate.

First, the social cost is always decreasing with the number of years of service. Though not surprising, this result was not guaranteed in advance. We could imagine expensive pension schemes that do not exhibit this property. If agents retire later; more contributions are collected, pension benefits are paid over a shorter period on average, the average wages

\footnotetext{
${ }^{15}$ The qualitative results are the same with a discounting rate of $2 \%$.
} 
Figure 11: Discounted value of the career (discount rate 3.5\%)

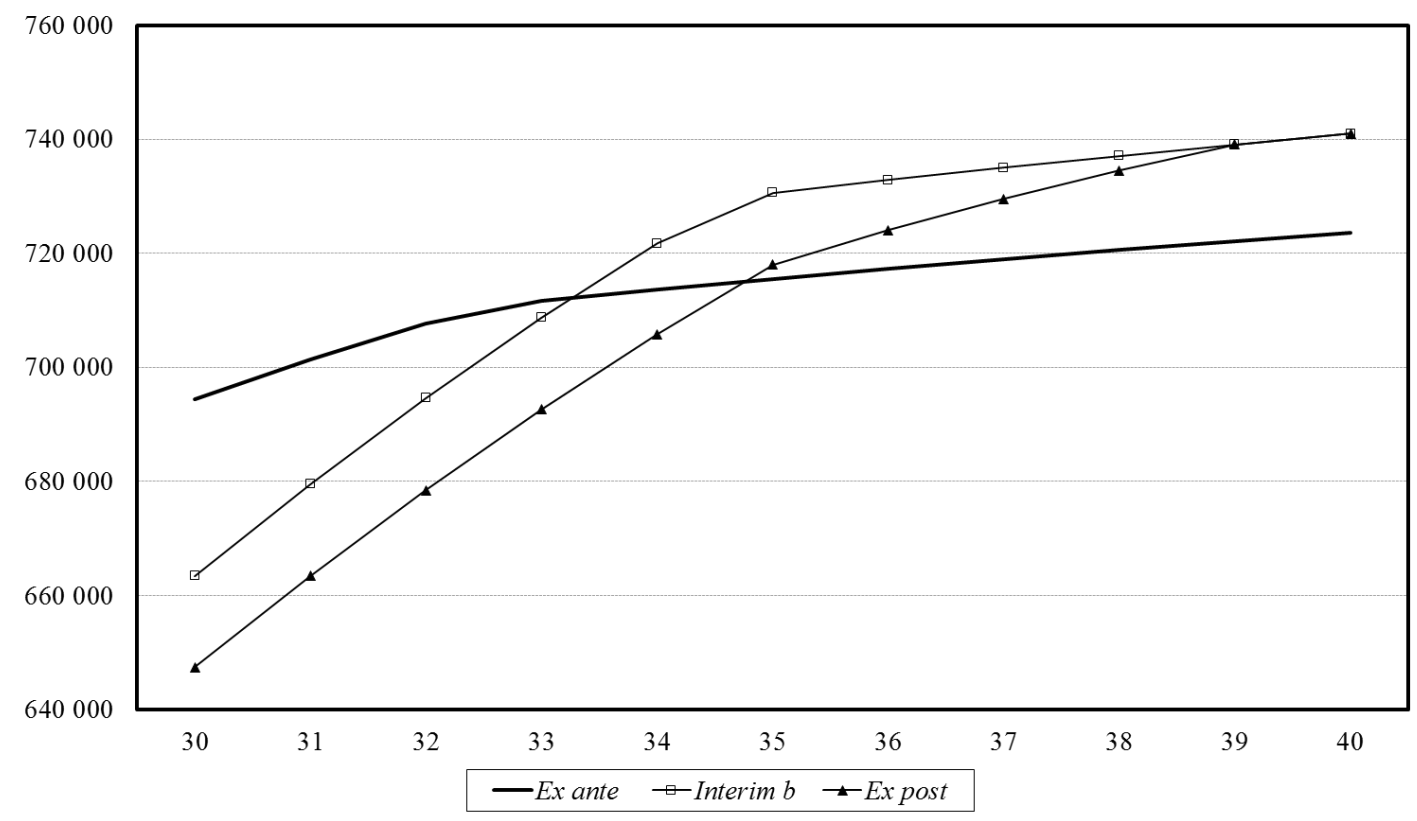

Figure 12: Actuarial cost per year of service (discount rate 3.5\%)

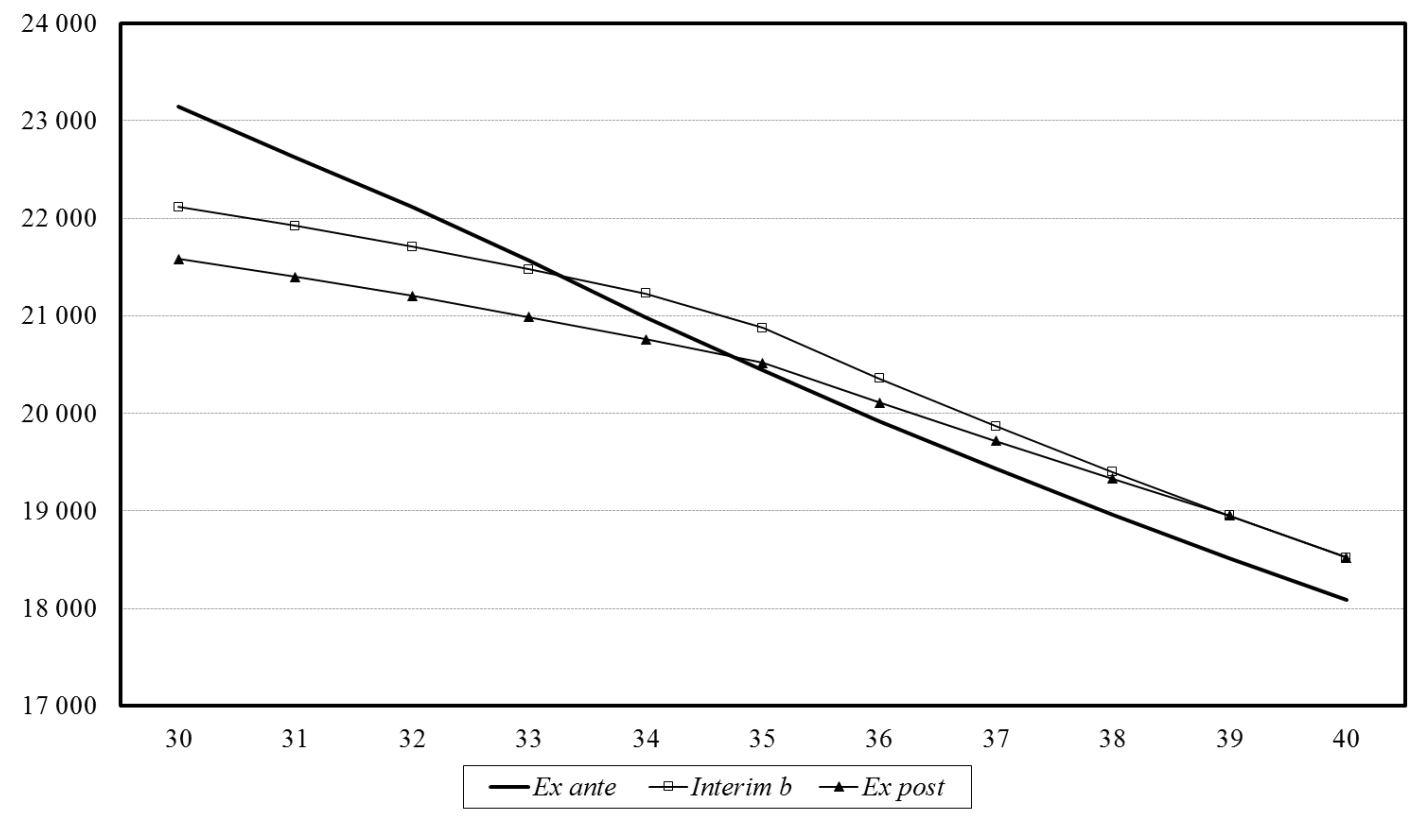


increase, due to higher seniority, but the labor cost per unit of product is reduced. A comparison of our measure of social cost before and after the reform, shows that the interim $b$ and ex post curves cross the ex ante curve, and remain above the latter for higher values of the length of service. This feature could be bad news, for it suggests that the reform could in fact increase demands on public money, if the agents massively decide to defer retirement!

As a matter of fact, we can show that the interim $b$ and ex post regimes, as depicted on Figure 12, are likely to save money... but only in the long run. To get a clear conclusion on the interim period, we have to study the interim a sub-regime separately, which complicates the analysis.

Call $c_{0}(\tau)$ and $c_{1}(\tau)$ the curves representing a train driver's social cost per year of service in the ex ante and interim $b$ regimes, respectively, as a function of seniority $\tau$ at the moment of retirement. (These curves are drawn on Figure 12). Let $m_{0}(\tau)$ and $m_{1}(\tau)$ be the probabilities of retiring with seniority $\tau$ in the ex ante and interim $b$ regimes, respectively. These two distributions are generated by different individual choice functions, derived before and after the reform. The reform will save public money at the interim $b$ stage, if and only if the average social cost per year of service decreases after the reform, that is, if the difference in average costs, denoted $\Delta$, is nonnegative, more precisely,

$$
\Delta=\sum_{\tau} c_{0}(\tau) m_{0}(\tau)-\sum_{\tau} c_{1}(\tau) m_{1}(\tau) \geq 0
$$

Assume that the social cost per year of service decreases with respect to the seniority at the age of retirement. This is consistent with facts, as shown by our computations (and Figure 12 above). Assume in addition that there exists a seniority-threshold, denoted $\tau^{*}$, such that $m_{1}(\tau)>m_{0}(\tau)$ if and only if $\tau>\tau^{*}$. This assumption means that the reform decreases the probability of retiring early (before $\tau^{*}$ ) and increases that of retiring later (after $\left.\tau^{*}\right){ }^{16}$ Under these assumptions, the reform will save money if it would save money in the hypothetical case in which individual decisions would not change. To prove this assertion, note first that $\Delta$ can be rewritten as follows,

$$
\Delta=\sum_{\tau}\left(c_{0}(\tau)-c_{1}(\tau)\right) m_{0}(\tau)+\sum_{\tau} c_{1}(\tau)\left(m_{0}(\tau)-m_{1}(\tau)\right)
$$

The first term of the expression is the cost variation when the retirement decisions are fixed. The second term gives the impact on costs of the change in the distribution of individual decisions. This second term is non-negative. Indeed, with the assumptions made above, we have

$$
\begin{aligned}
\sum_{\tau} c_{1}(\tau)\left(m_{0}(\tau)-m_{1}(\tau)\right) & =\sum_{\tau \leq \tau^{*}} c_{1}(\tau)\left(m_{0}(\tau)-m_{1}(\tau)\right)+\sum_{\tau>\tau^{*}} c_{1}(\tau)\left(m_{0}(\tau)-m_{1}(\tau)\right) \\
& \geq c_{1}\left(\tau^{*}\right)\left[\sum_{\tau \leq \tau^{*}}\left(m_{0}(\tau)-m_{1}(\tau)\right)\right]+c_{1}\left(\tau^{*}\right)\left[\sum_{\tau>\tau^{*}}\left(m_{0}(\tau)-m_{1}(\tau)\right)\right] \\
& \geq c_{1}\left(\tau^{*}\right) \sum_{\tau}\left[m_{0}(\tau)-m_{1}(\tau)\right]=0
\end{aligned}
$$

${ }^{16}$ This assumption implies first-order stochastic dominance. 
Table 1: Distribution of age at retirement

\begin{tabular}{lllll}
\hline & 2007 & 2008 & 2009 & 2010 \\
\hline Under 35 years & $0 \%$ & $0 \%$ & $0 \%$ & $0.07 \%$ \\
\hline 35 to 49 years & $3.55 \%$ & $4.90 \%$ & $5.05 \%$ & $7.96 \%$ \\
\hline 50 to 54 years & $56.83 \%$ & $53.44 \%$ & $53.25 \%$ & $53.39 \%$ \\
\hline 55 to 59 years & $28.91 \%$ & $30.02 \%$ & $27.98 \%$ & $28.81 \%$ \\
\hline 60 to 65 years & $10.60 \%$ & $11 \%$ & $13.54 \%$ & $9.21 \%$ \\
\hline Over 65 years & $0.11 \%$ & $0.64 \%$ & $0.18 \%$ & $0.55 \%$ \\
\hline Total & $100 \%$ & $100 \%$ & $100 \%$ & $100 \%$ \\
\hline
\end{tabular}

Source : RATP Pension Fund, Annual Reports 2008, 2009, 2010.

since $\Sigma_{\tau} m_{0}(\tau)=\Sigma_{\tau} m_{1}(\tau)=1$. We conclude that,

$$
\Delta \geq \sum_{\tau}\left(c_{0}(\tau)-c_{1}(\tau)\right) m_{0}(\tau)
$$

Thus, the reform will reduce social costs provided that these costs would also be reduced if retirement decisions did not change. Of course, it is likely that the decisions to retire will change, but the latter changes will contribute to decrease the costs even more.

It seems that these sufficient conditions for social cost reduction are actually satisfied if we consider the data. The conditions are at least likely to be met in the interim $b$ situation. As shown by Figure 13, the interim $b$ cost curve $c_{1}(\tau)$ is below the ex ante $c_{0}(\tau)$ for $\tau$ smaller than their intersection point, corresponding to a seniority of 33 years (or an age of 55). It follows that for retirement ages below 55, the reform will reduce the average cost per year of service, essentially because of early retirement penalties.

The RATP pension fund provides us with information on the probability distribution $m_{0}$, given by Table 1 and Table 2 .

Tables 1 and 2 show that until recently, the RATP employees have massively taken up the opportunity to retire early; $50 \%$ of the employees leave the firm between 50 and 54 and $30 \%$ leave between 55 and 59 . Thus, the largest weights $m_{0}(\tau)$ multiply the differences $c_{0}(\tau)-c_{1}(\tau)$, that happen to be positive, while a smaller fraction of the population retires in the interval where $c_{0}(\tau)-c_{1}(\tau)<0$. This explains why the term $\sum_{t}\left(c_{0}(\tau)-c_{1}(\tau)\right) m_{0}(\tau)$ is likely to be positive in practice and hence, the reform should save public money in the $e x$ post stage, as well as in the interim $b$ stage.

To see where a potential increase in social costs is hidden, a closer inspection of the reform is required. If we focus on the interim a situation, our judgment will change. Figures 
Table 2: Average age and contribution length at retirement

\begin{tabular}{llll}
\hline & 2008 & 2009 & 2010 \\
\hline Average age (years) & & & \\
\cline { 1 - 1 } & & 53.95 & 53.70 \\
\hline - of total personnel & 54.8 & 52.07 & 52.26 \\
\hline - of train drivers & 52.02 & & 33.57 \\
\hline $\begin{array}{l}\text { Contribution length } \\
\text { (years) }\end{array}$ & & 33.38 & 34.14 \\
\hline - of total personnel & 32.47 & 32.01 & \\
\hline -of train drivers & 31.18 & & \\
\hline
\end{tabular}

Source : RATP Pension Fund, Annual Reports 2008, 2009, 2010

13 and 14 allow for a comparison of the career values and the costs per year of service in the four situations: ex ante, interim $a$, interim $b$ and ex post.

The interim a cost curve is the bold dashed line on Figure 13: it lies strikingly above the ex ante curve. Without any ambiguity, the agents falling under the interim a regime will cost more to society regardless of their retirement age choice. For the cohorts born between 1957 and 1967, who are entitled to retirement between 2007 and 2017, the reform turns out to raise the social cost per year of service by $2 \%$ (using a discount rate of $2 \%$ ). Starting from the year 2024, the interim $b$ regime will fully apply since the workers that will then retire will have been hired before 2009. When this point will be reached, the pension regime will start to generate savings, the magnitude of which will depend on individual retirement decisions. The ex post rules should eventually produce substantial gains but they will come into effect around 2040. The interim $a$ and $b$ regimes capture the situation of the RATP pension regime in the coming decade, and the social costs are expected to increase.

To refine our assessment, we should evaluate the respective weight of the agents falling under the interim $a$ and interim $b$ regimes and compute a weighted average. We use information about the distribution of personnel age and seniority in 2007. Using these data, it turns out that in $2007,62 \%$ of the active drivers fall under the interim a (and $38 \%$ under interim $b$ ) regime ${ }^{17}$. Figure 15 permits a comparison of the weighted average interim cost with the ex ante cost. It shows that with a 3.5\% discount rate, the two curves are close to each other and, starting from 31 years of service, the (average) interim curve is higher than the ex ante curve. During the interim situation, no savings are expected because the generous conditions under interim $a$ are offsetting the potential economies allowed by the

\footnotetext{
${ }^{17}$ This has to be done prudently because of the transitory period for workers born between 1967 and 1972 (period during which the rules gradually evolve from one interim situation to the other). We adopt a simple convention that agents born in that range are split equally between interim $a$ and interim $b$.
} 
Figure 13: Discounted value of career (discount rate: $3.5 \%$ )

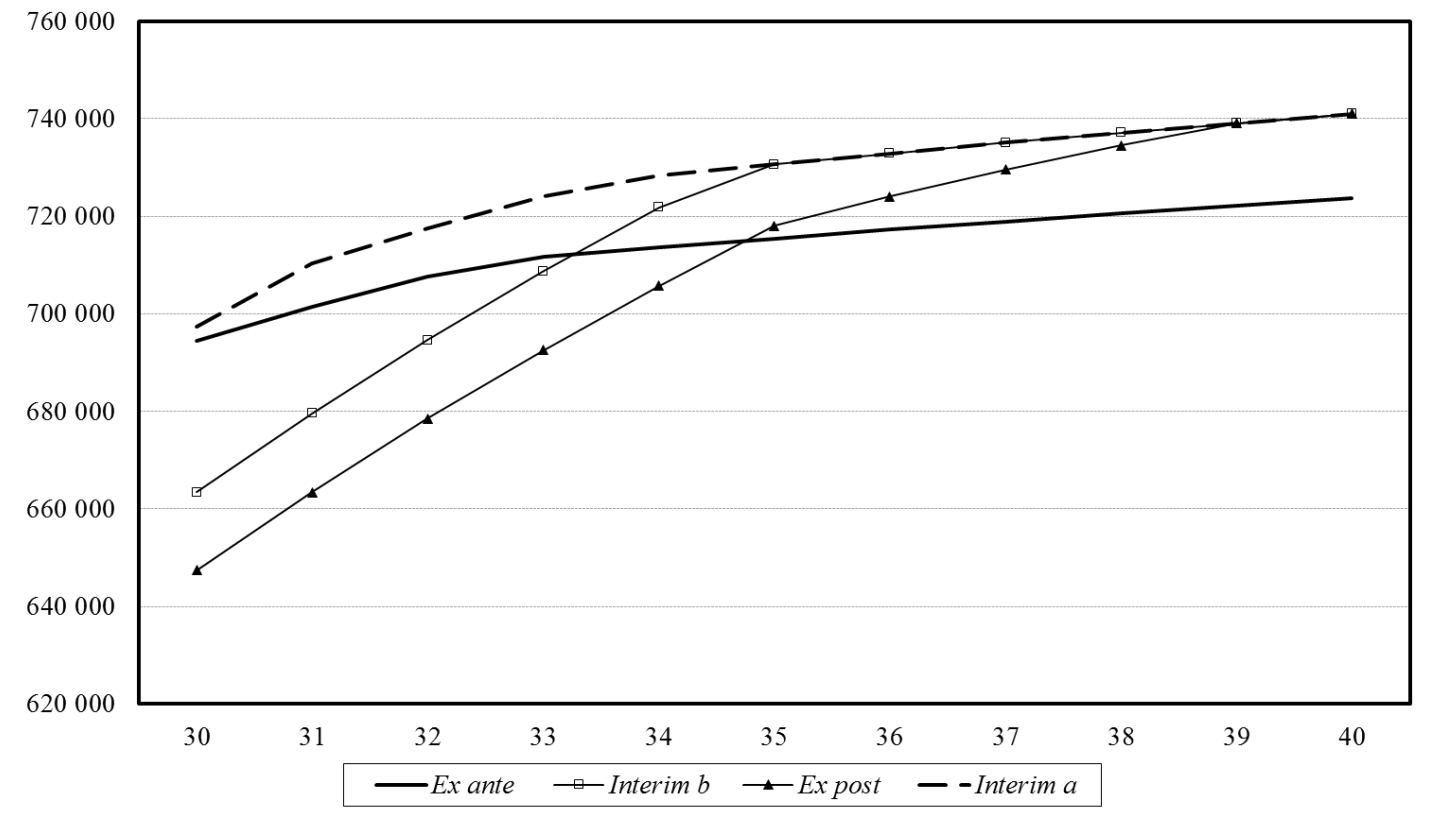

Figure 14: Actuarial cost per year of service (discount rate: $3.5 \%$ )

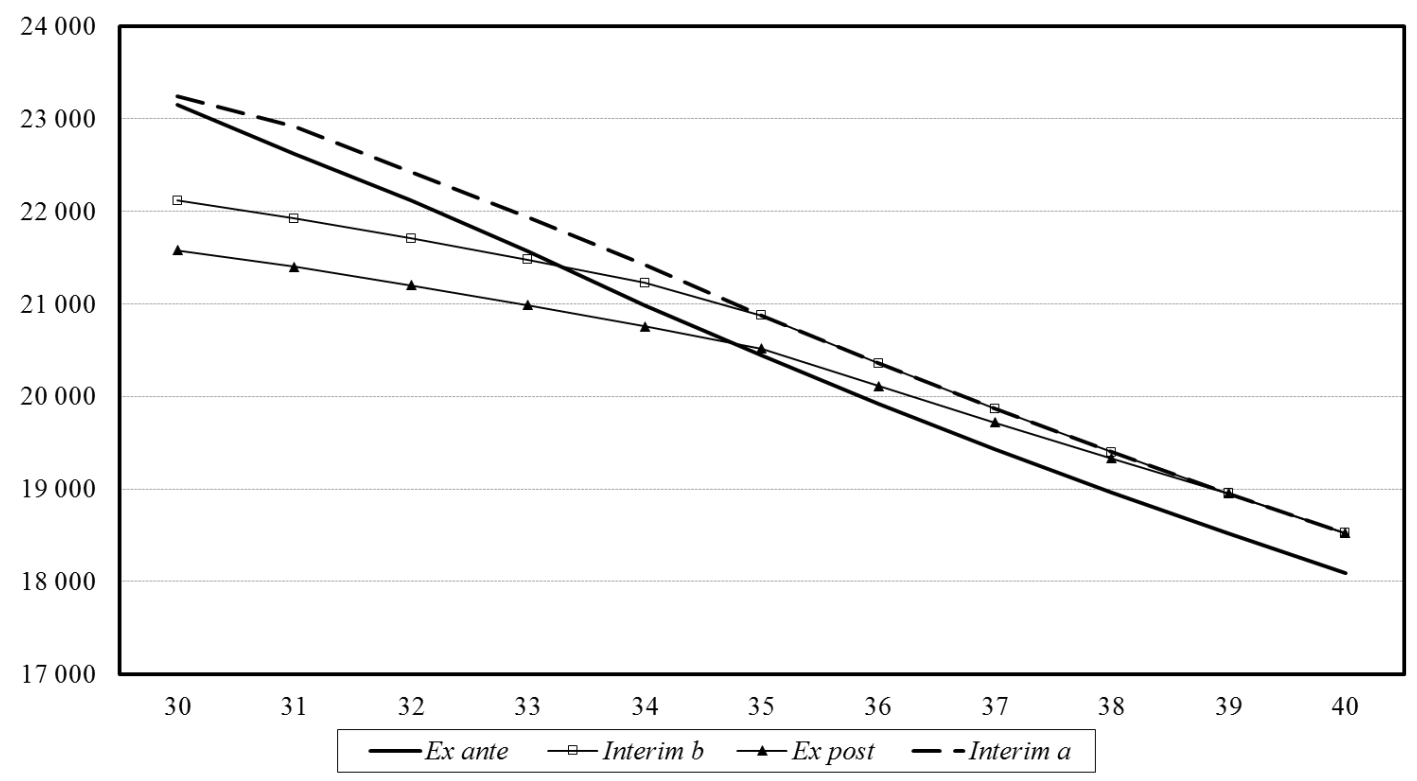


Figure 15: Actuarial cost per year of service, interim and ex ante (discount rate: $3.5 \%$ )

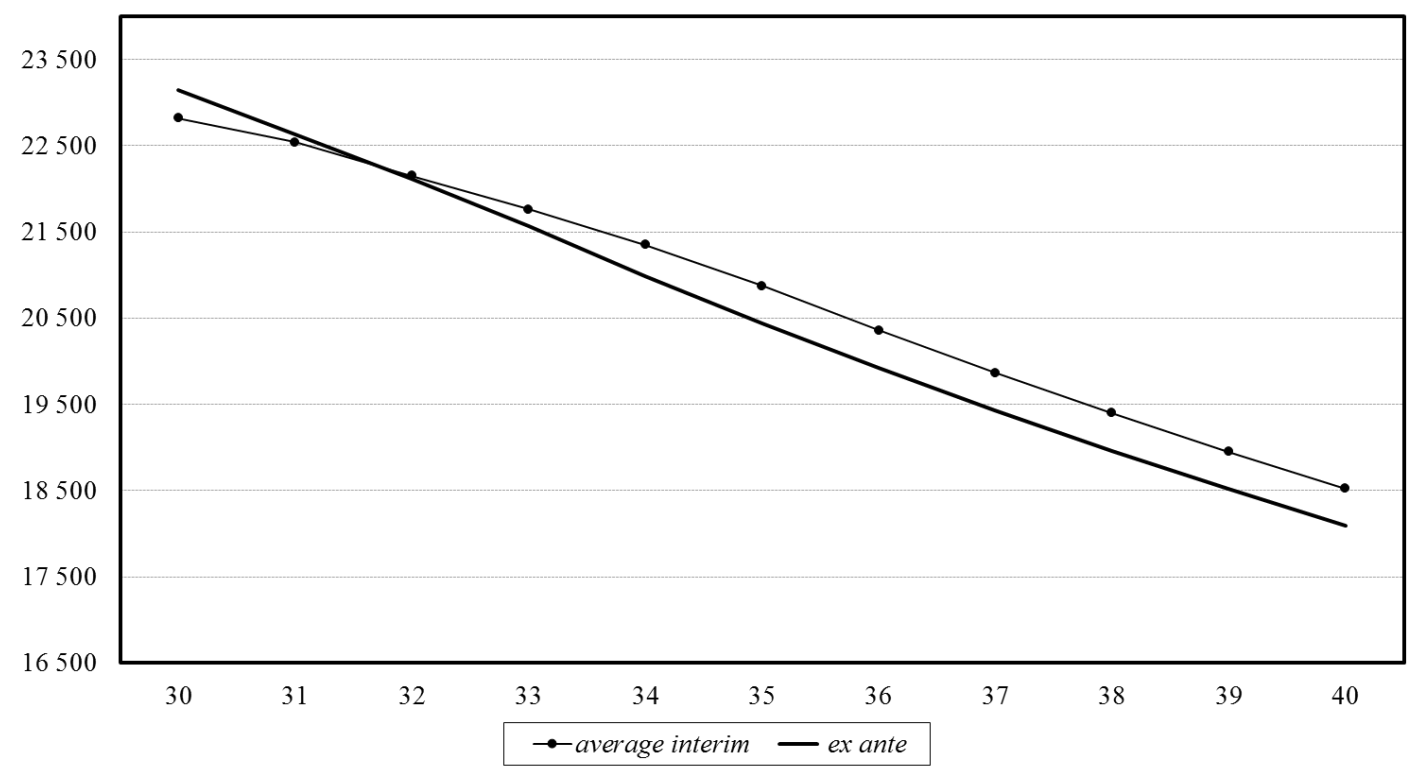

interim $b$ rules.

\section{Conclusion}

To evaluate pension-regime reforms in public services such as urban transportation companies, we put forward a simple criterion: the actuarial cost of a worker per year of service. This measure of cost is the discounted and expected sum of all net real salaries and pensions of a worker with lifetime employment in the firm, divided by the number of years of service. With the help of a simple model, we have shown that if the public authorities' objective is to minimize the actuarial cost per year of service, subject to individual rationality constraints, then the pension reform problem is not a zero-sum game. More precisely, there may exist reforms such that (i), the actuarial cost of a worker per year of service is reduced, (ii) the utility of workers does not decrease and (iii) the pension fund deficit does not increase. These reforms improve social efficiency in a very clear sense. Workers can accept a deal according to which they postpone retirement in exchange for increased salaries and pensions. This type of agreement can lead to a welcome reduction of public subsidies to the public employees' pension funds. We then applied our criterion to the 2008 pension reform of the Paris metro. We focused on the special case of train drivers and showed that the reform rests on some sound principles. To create incentives to postpone retirement, steps were added to the wage schedule, penalties for early retirement were introduced. But we show that the reform is going to increase public costs in the years to come, because of generous measures, granted during a long transition period. The public authorities have paid older workers and insiders for the right to enact a reform that will apply to young recruits, in a distant future. 


\section{$5 \quad$ References}

Barr, Nicholas, and Peter A. Diamond (2008), Reforming pensions. Principles and policy choices, Oxford University Press, Oxford, UK.

Beshears, John, James J. Choi, David Laibson, Brigitte C. Madrian, and Stephen P. Zeldes (2014), "What makes annuitization more appealing?" Journal of Public Economics, 116, pp $2-16$.

Biggs, Andrew G. (2014), "Not so modest: pension benefits for full-career state government employees," American Enterprise Institute, http://www.aei.org/publication/.

Blau, David M. (2008), "Retirement and consumption in a life-cycle model", Journal of Labor Economics, 26, pp 35-71.

Bozio, Antoine and Thomas Piketty (2008), Pour un nouveau système de retraites. Des comptes individuels de cotisations financés en répartition, Collection Cepremap, Editions Rue d'Ulm, Presses de l'Ecole normale supérieure, Paris.

Burtless, Gary (1986), "Social security, unanticipated benefit increases, and the timing of retirement", Review of Economic Studies, 53(5), pp 781-805.

Chalmers, John, Woodrow T. Johnson, and Jonathan Reuter, (2014), "The effect of pension design on employer costs and employee retirement choices: Evidence from Oregon", Journal of Public Economics, 116, pp 17-34.

Clark, Robert L., Melinda Sandler Morrill, and David Vanderweide, (2014), "Defined-benefit pension-plan distribution decisions by public sector employees", Journal of Public Economics, 116, pp 73-88.

Coeffic, Nicole (1999), "Le cumul emploi-retraite: plus fréquent chez les hommes de moins de 60 ans", Etudes et Résultats, no 14, DREES, Ministère de l'emploi et de la solidarité, Paris, France.

Coile, Courtney and Jonathan Gruber (2007), "Future social security entitlements and the retirement decision", Review of Economics and Statistics, 89(2), pp 234-246.

Cour des comptes (2006), "Les régimes spéciaux de retraite des industries électriques et gazières, de la RATP et de la SNCF", chapter 10 in: Rapport public annuel, La Documentation Française, Paris.

Cour des comptes (2009), Rapport public annuel, La Documentation Française, Paris.

Diamond, Peter A. (2002), Taxation, incomplete markets and Social Security, the $2000 \mathrm{Mu}-$ nich Lectures, MIT Press, Cambridge, Massachusetts.

Eckert, Christian (2014), Rapport sur le projet de loi de finances pour 2014, Annexe 39. Régimes sociaux et de retraites; pensions. Document 1428, Assemblée Nationale, Paris, France. 
Feldstein, M. (1974) "Social security, induced retirement and aggregate capital accumulation", Journal of Political Economy, 82, pp 905-926.

French, Eric (2005), "The effects of health, wealth, and wages on labour supply and retirement behaviour", Review of Economic Studies, 72(2), pp 395-427.

Glaeser Edward L., and Giacomo A.M. Ponzetto, (2014), "Shrouded costs of government: The political economy of state and local public pensions", Journal of Public Economics, 116, pp 89-105.

Gustman, Alan L. and Thomas L. Steinmeier (1986), "A structural retirement model", Econometrica, 54(3), pp 555-584.

Hairault, Jean-Olivier, Langot, François and Thepthida Sopraseuth (2010), "Distance to retirement and older workers' employment: the case for delaying the retirement age", Journal of the European Economic Association, 8(5), pp 1034-1076.

INED (2011), Table de mortalité générale des années 2007-2009, Institut National d'Etudes Démographiques, Paris, France.

Jaaidane, Touria et Robert Gary-Bobo (2008), "Salaires et carrières dans la fonction publique: le cas des éboueurs", Revue française d'économie, 22(3), pp 3-59.

Mailath, George and Andrew Potlewaite (1990), "Asymmetric Information Bargaining Problems with Many Agents", Review of Economic Studies, 57, pp 351-367.

Novy-Marx, Robert and Joshua D. Rauh (2011a), "Public pension promises: how big are they and what are they worth?", Journal of Finance, 66(4), pp 1211-1249.

Novy-Marx, Robert and Joshua D. Rauh (2011b), "The crisis in local government pensions in the United States", Chapter 3 in: R. Litan and R. Herring eds., Growing old: Paying for retirement and institutional money management after the financial crisis, Brookings Institution, Washington, D.C, pp 47-74.

Novy-Marx, Robert and Joshua D. Rauh, (2014), "Linking benefits to investment performance in US public pension systems", Journal of Public Economics, 116, pp. 47-61.

RATP (2009), " Réforme du régime spécial de retraites RATP. Mesures d'accompagnement prévues par l'entreprise", Note à l'attention du conseil d'orientation des retraites, Conseil d'orientation des retraites, Paris, France, www.cor-retraites.fr/IMG/pdf/doc-1089.pdf.

Rob, Rafael (1989), "Pollution claims settlements under private information", Journal of Economic Theory, 47, pp 307-333.

Rust, John and Christopher Phelan (1997), "How social security and Medicare affect retirement behavior in a world of incomplete markets", Econometrica, 65(4), pp 781-831.

Stock, James H. and David A. Wise (1990), "Pensions, the option value of work, and retirement", Econometrica, 58(5), pp. 1151-1180. 


\section{Appendix}

\subsection{Appendix A. Empirical implementation}

Let $\pi(t)$ denote the unconditional probability of dying at age $t \geq 0$. Let $F(t)=\operatorname{Pr}(a<t)$ be the probability of dying at an age $a$ smaller than $t$. Moreover, define $\pi\left(a \mid t_{1}\right)$ the probability of dying at the age $a$, given that the age $t_{1}$ has been reached. If $a \leq t_{1}$ one has $\pi\left(a \mid t_{1}\right)=0$, and if $a>t_{1}$,

$$
\pi\left(a \mid t_{1}\right)=\frac{\pi(a)}{1-F\left(t_{1}\right)} .
$$

Each agent has a disutility of labor, denoted $\theta$. Let $U\left(a, t_{1}, \theta\right)$ denote the discounted value of utilities $u_{t}$ at age $t_{1}$ if the agent dies at age $a$ and let $U\left(t_{1}, \theta\right)$ denote the expected utility, knowing $t_{1}$.

$$
U\left(a, t_{1}, \theta\right)=\sum_{t=t_{1}}^{a} \frac{u_{t}}{(1+r)^{t-t_{1}}}
$$

Taking the expectation over $a$ given $t_{1}$, we have the following:

$$
\mathbf{U}\left(t_{1}, \theta\right)=\sum_{a=t_{1}}^{100} \sum_{t=t_{1}}^{a} \frac{\pi\left(a \mid t_{1}\right) u_{t}}{(1+r)^{t-t_{1}}}=\sum_{t=t_{1}}^{100}\left(\sum_{\alpha \geq t} \pi\left(\alpha \mid t_{1}\right)\right) \frac{u_{t}}{(1+r)^{t-t_{1}}}=\sum_{t=t_{1}}^{100} \frac{s\left(t \mid t_{1}\right) u_{t}}{(1+r)^{t-t_{1}}}
$$

where $s\left(t \mid t_{1}\right)=1-F\left(t \mid t_{1}\right)$ is the survival at age $t$ given that age $t_{1}$ has been reached.

Letting $s(t)=1-F(t)$, if we want to evaluate a career at age $t_{1}$, for instance, we have

$$
s\left(t \mid t_{1}\right)=\frac{1-F(t)}{1-F\left(t_{1}\right)}=\frac{s(t)}{s\left(t_{1}\right)}
$$

for $t>t_{1}$.

The maximization of $U$ yields a decision function, denoted $d^{*}$, which gives seniority at the moment of retirement as a function of the agent's disutility type $\theta$ and of the age $t_{0}$ at which the agent started her career, i.e., $\tau=d^{*}\left(t_{0}, \theta\right)$. The seniority at the moment of retirement is random from the econometrician's point of view, because it relies on unobserved characteristics $\theta$.

Let $h\left(t_{0}\right)$ be the frequency of individuals enrolled at age $t_{0}$. Let $G(\theta)$ denote the distribution of type $\theta$. By definition, the joint probability, denoted $m$, of retiring with seniority $\tau$ when enrolled at age $t_{0}$, is derived from $G$,

$$
m\left(\tau, t_{0}\right)=\operatorname{Pr}\left[\left\{\theta \mid d^{*}\left(t_{0}, \theta\right)=\tau\right\}\right] .
$$

The conditional and marginal probabilities can also be computed. The probability of choosing to retire with seniority $\tau$ given $t_{0}$ is denoted $\mu\left(\tau \mid t_{0}\right)$. It gives the frequency of the values of $\theta$ leading agents, enrolled at age $t_{0}$, to retire with seniority $\tau$. The average probability of retiring with seniority $\tau$ is then

$$
m(\tau)=\sum_{t_{0}} \mu\left(\tau \mid t_{0}\right) h\left(t_{0}\right)
$$


Finally, we need the probability of having started a career at age $t_{0}$, given that seniority is $\tau$ at the moment of retirement. This latter probability is denoted $\lambda$ and can be written,

$$
\lambda\left(t_{0} \mid \tau\right)=\frac{\mu\left(\tau \mid t_{0}\right) h\left(t_{0}\right)}{m(\tau)} .
$$

The average total cost of an agent retiring with seniority $\tau$ is defined as follows,

$$
v(\tau)=\sum_{t_{0}} C\left(t_{0}, t_{0}, \tau\right) \lambda\left(t_{0} \mid \tau\right)
$$

and the agent's social cost per year of service is defined as $c(\tau)=v(\tau) / \tau$.

\subsection{Appendix B. Institutional context}

RATP is the public transport operator in the Paris region. ${ }^{18}$ Personnel is covered by a pay-as-you-go, defined-benefits pension system. Employees are classified according to their occupations. Administrative personnel are called "sedentary". Workers assigned to maintenance and drivers are called "active". In 2004, almost $85 \%$ of the RATP employees were classified as active. We focus on the metro drivers.

\subsubsection{The pension scheme before the reform}

Before the reform, a sedentary agent could claim a pension benefit at 60, provided he (she) had served during 30 years at least. Active workers, like train drivers, were granted years as a bonus to compensate for difficult work conditions. A train driver who had worked and contributed to the pension system during 25 years had the opportunity to retire at the age of 50 .

Before the reform, a full-rate pension could be claimed after 37.5 years of career and would amount to $75 \%$ of the employee's final ${ }^{19}$ gross salary. For each year of contribution, an accrual rate of $2 \%$ applied. Early retirement was not penalized.

\subsubsection{The RATP pension fund and the 2008 act}

Until the end of 2005, the company was responsible for the pension liabilities of its special scheme. Pension contribution rates were respectively $7.85 \%$ of gross salary for the employee and $15.34 \%$ for the employer. These contributions were not sufficient. A public agency, the Paris Region Transport Syndicate, subsidized the company to cover the structural shortfalls of the pension scheme. At the beginning of 2006, a RATP pension fund was created ${ }^{20}$, legally and financially independent of the firm itself. The contribution rates have been increased, to $12 \%$ and $18 \%$ for the employees and the employer, respectively. The contribution base

\footnotetext{
${ }^{18}$ In 2010, the firm employed 44,795 agents, transported 3.06 billions of passengers and its sales totaled $€ 4.2$ billions (Source: RATP Social reports and publications).

${ }^{19}$ The final salary is the compensation attached to the position occupied during the last six months of career.

${ }^{20}$ This creation aimed at ensuring compliance with international accounting norms and because direct State subsidies to the company are illegal under EU Competition Law.
} 
was enlarged thanks to an additional $2.4 \%$ increase of the base salary to compensate for the increase in the contribution rate. Data obtained from the RATP pension fund show that the contributions of both the employees and the employer were structurally too low and that a State subsidy was needed each year to honor the pension bill. The State subsidy still represents more than $50 \%$ of the fund resources. ${ }^{21}$

Under the 2008 reform, the contribution length required for a full-rate benefit was gradually increased from 37.5 years to 40 years by 2016. Table 3 shows the timing of RATP special pension scheme reforms $(2008,2010)$.

A penalty (deduction) reduces the pension rate when the contribution length is smaller than the requirement for a full pension. This measure became effective as of July 1, 2010. When the contribution period exceeds the duration required for full-rate benefits and when the agent has reached the age of 60 , a premium will be applied to the pension for each additional quarter in the length of service. A number of pay-raise and pension-padding measures $^{22}$ were adopted which impact the value of careers:

- The workers' wage scale is extended with 2 additional steps, reached by seniority. ${ }^{23}$

- A wage increase, dubbed "retirement points", has been granted. More precisely, the increase is staggered: one third of it will be granted when the agent reaches 28 years of seniority; the second at 29 years and the last after 30 years.

After 2016, all these compensatory measures will be effective. The reform in fact created 4 additional steps at the top of the worker's wage schedule (taking the so-called retirement points into account). The combined impact of these steps is a $5.7 \%$ increase of the pre-reform wage attached to the last step.

- Between 2008 and 2011, on July 1, an increase of $0.6 \%$ of the base salary is planned (an increase of $2.4 \%$ in total). As a consequence, both the level of contributions to the pension fund and the pension benefits will be affected.

- Moreover, it is worth noting that the impact of the reform on the pensions of employees who decided to retire between July 2008 and July 2012 has been completely offset by a number of additional specific transitory measures. Thus, the oldest insiders are completely immunized.

\subsubsection{The 2010 public pensions act}

The 2010 act reviewing all civil service pensions, introduces a further 2-year increase in the minimum retirement age. But the increase is gradual, being spread over 8 years. As a consequence, the normal retirement age of RATP workers is then set to rise by 2 years before 2023. To take the fact that the 2008 act already reformed their pension system into account, the 2010 act will not apply to RATP employees until 2017. The minimal retirement age of train drivers is now 52 (instead of 50) for agents born after January 1972. Their minimal length of service will be 27 years (instead of 25). Again, this measure will be applied gradually to agents born between 1967 and 1972.

\footnotetext{
${ }^{21}$ Source: RATP pension fund, Annual reports, 2008, 2010.

${ }^{22}$ See RATP (2009).

${ }^{23}$ After 26 years of service, an agent is eligible for the first additional step. This measure was effective as of January 1, 2012. With 28 years of seniority, he(she) reaches the second additional position (a measure effective on January 1, 2014).
} 
Table 3: Timing of RATP special pension scheme reforms (2008, 2010)

\begin{tabular}{|c|c|c|c|c|c|c|}
\hline $\begin{array}{l}\text { Semester } \\
\text { at which } \\
\text { the agent is } \\
\text { eligible for } \\
\text { retirement }\end{array}$ & $\begin{array}{l}\text { Contribution } \\
\text { length } \\
\text { required for } \\
\text { full benefit } \\
\text { (years) }\end{array}$ & $\begin{array}{l}\text { Accrual } \\
\text { rate }\end{array}$ & $\begin{array}{l}\text { Deduction } \\
\text { rate per } \\
\text { missing } \\
\text { quarter }\end{array}$ & $\begin{array}{l}\text { Minimal } \\
\text { retirement } \\
\text { age for } \\
\text { active agents }\end{array}$ & $\begin{array}{l}\text { Normal } \\
\text { retirement } \\
\text { age }\end{array}$ & $\begin{array}{l}\text { Minimal } \\
\text { length of } \\
\text { service for } \\
\text { active } \\
\text { agents }\end{array}$ \\
\hline 2007 & 37.5 & $2 \%$ & $0 \%$ & \multirow{18}{*}{50 years } & & \multirow{18}{*}{25 years } \\
\hline $07 / 01 / 2008$ & 37.75 & $1.987 \%$ & $0 \%$ & & & \\
\hline $01 / 01 / 2009$ & 38 & $1.974 \%$ & $0 \%$ & & & \\
\hline $07 / 01 / 2009$ & 38.25 & $1.961 \%$ & $0 \%$ & & & \\
\hline $01 / 01 / 2010$ & 38.5 & $1.948 \%$ & $0 \%$ & & & \\
\hline $07 / 01 / 2010$ & 38.75 & $1.935 \%$ & $0.125 \%$ & & EAR+1 year & \\
\hline $01 / 01 / 2011$ & 39 & $1.923 \%$ & $0.125 \%$ & & EAR+1 & \\
\hline $07 / 01 / 2011$ & 39.25 & $1.911 \%$ & $0.25 \%$ & & EAR+ 1.5 & \\
\hline $01 / 01 / 2012$ & 39.5 & $1.899 \%$ & $0.25 \%$ & & $\mathrm{EAR}+1,5$ & \\
\hline $07 / 01 / 2012$ & 39.75 & $1.887 \%$ & $0.375 \%$ & & $\mathrm{EAR}+2$ & \\
\hline $01 / 01 / 2013$ & 40 & $1.875 \%$ & $0.375 \%$ & & $\mathrm{EAR}+2$ & \\
\hline $07 / 01 / 2013$ & 40.25 & $1.863 \%$ & $0.50 \%$ & & EAR+2.25 & \\
\hline $01 / 01 / 2014$ & 40.25 & $1.863 \%$ & $0.50 \%$ & & EAR+2.25 & \\
\hline $07 / 01 / 2014$ & 40.5 & $1.852 \%$ & $0.625 \%$ & & EAR+2.5 & \\
\hline $01 / 01 / 2015$ & 40.5 & $1.852 \%$ & $0.625 \%$ & & EAR+2.5 & \\
\hline $07 / 01 / 2015$ & 40.75 & $1.840 \%$ & $0.75 \%$ & & EAR+2.75 & \\
\hline $01 / 01 / 2016$ & 40.75 & $1.840 \%$ & $0.75 \%$ & & EAR+2.75 & \\
\hline $07 / 01 / 2016$ & 41 & $1.829 \%$ & $0.875 \%$ & & EAR+3 & \\
\hline $07 / 01 / 2017$ & 41.25 & $1.818 \%$ & $1 \%$ & $\begin{array}{l}50 \text { years }+4 \\
\text { months }\end{array}$ & $\mathrm{EAR}+3.25$ & $\begin{array}{l}25 \text { years }+4 \\
\text { months }\end{array}$ \\
\hline $07 / 01 / 2018$ & 41.5 & \multirow{7}{*}{$1.807 \%$} & $1.125 \%$ & $50+8$ months & $\mathrm{EAR}+3.5$ & $\begin{array}{l}25+8 \\
\text { months }\end{array}$ \\
\hline 07/01/2019 & 41.5 & & \multirow{6}{*}{$1.25 \%$} & 51 & $\mathrm{EAR}+3.75$ & 26 \\
\hline $07 / 01 / 2020$ & 41.5 & & & $51+4$ months & $\mathrm{EAR}+4$ & $\begin{array}{l}26+4 \\
\text { months }\end{array}$ \\
\hline $07 / 01 / 2021$ & 41.5 & & & $51+8$ months & $\mathrm{EAR}+4.25$ & $\begin{array}{l}26+8 \\
\text { months }\end{array}$ \\
\hline $07 / 01 / 2022$ & 41.5 & & & \multirow{3}{*}{52} & EAR+4.5 & \multirow{3}{*}{27} \\
\hline $07 / 01 / 2023$ & 41.5 & & & & EAR+4.75 & \\
\hline $07 / 01 / 2024$ & 41.5 & & & & $\mathrm{EAR}+5$ & \\
\hline
\end{tabular}

EAR : Eligibility Age for Retirement

Source : RATP pension fund 


\subsection{Appendix C. Employee compensation}

As in the civil service, a number of points is attached to each grade and step of the general compensation schedule. The train drivers' pay scale has 10 grades which are themselves divided into 15 steps. The employee spends 2 years on each step and mechanically reaches the different grades. Promotions are determined by seniority exclusively. The base salary at any given grade and step is the product of the number of points by a coefficient called point value.

In 2008 , the point value had decreased by $15 \%$ in real terms since 1981 . The senioritybased promotions tend to reduce employee sensitivity to wage erosion, if not to render it completely painless. ${ }^{24}$ Yet, the erosion of base wages obviously induces a decline in the value of careers. In such a context, the generous provisions of the special pension scheme might have been the last advantage enjoyed by RATP drivers, as compared to similar private-sector workers.

To carry out our evaluation, we computed a train driver's total compensation, including bonuses, and the take-home pay, net of various taxes and compulsory social contributions. We took major bonuses into account. For instance, all employees receive a "13th month" at the end of each year. We also computed the retirement benefits.

\footnotetext{
${ }^{24}$ More generally, the decline in real wages in the French public sector began around 1982-1983, see Jaaidane and Gary-Bobo (2008).
} 